\title{
Ecohydrologic controls on vegetation density and evapotranspiration partitioning across the climatic gradients of the central United States
}

\author{
J. P. Kochendorfer and J. A. Ramírez \\ Department of Civil and Environmental Engineering, Colorado State University, Ft. Collins, CO 80523, USA
}

Received: 17 January 2008 - Published in Hydrol. Earth Syst. Sci. Discuss.: 11 March 2008

Revised: 14 October 2010 - Accepted: 18 October 2010 - Published: 27 October 2010

\begin{abstract}
The soil-water balance and plant water use are investigated over a domain encompassing the central United States using the Statistical-Dynamical Ecohydrology Model (SDEM). The seasonality in the model and its use of the twocomponent Shuttleworth-Wallace canopy model allow for application of an ecological optimality hypothesis in which vegetation density, in the form of peak green leaf area index (LAI), is maximized, within upper and lower bounds, such that, in a typical season, soil moisture in the latter half of the growing season just reaches the point at which water stress is experienced. Via a comparison to large-scale estimates of grassland productivity, modeled-determined peak green LAI for these systems is seen to be at least as accurate as the unaltered satellite-based observations on which they are based. A related feature of the SDEM is its partitioning of evapotranspiration into transpiration, evaporation from canopy interception, and evaporation from the soil surface. That partitioning is significant for the soil-water balance because the dynamics of the three processes are very different. Surprising little dependence on climate and vegetation type is found for the percentage of total evapotranspiration that is soil evaporation, with most of the variation across the study region attributable to soil texture and the resultant differences in vegetation density. While empirical evidence suggests that soil evaporation in the forested regions of the most humid part of the study region is somewhat overestimated, model results are in excellent agreement with observations from croplands and grasslands. The implication of model results for waterlimited vegetation is that the higher (lower) soil moisture content in wetter (drier) climates is more-or-less completely
\end{abstract}

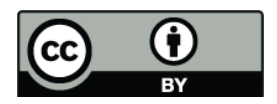

Correspondence to: J. A. Ramírez (ramirez@engr.colostate.edu) offset by the greater (lesser) amount of energy available at the soil surface. This contrasts with other modeling studies which show a strong dependence of evapotranspiration partitioning on climate.

\section{Introduction}

One of the foci of the emerging discipline of ecohydrology is to gain a better understanding of the role of plant water use in the soil-water balance (Rodriguez-Iturbe, 2000). Many water balance models lump plant water use, i.e., transpiration, with evaporation from canopy interception and from the soil surface under the rubric of evapotranspiration. Recently, Newman et al. (2006) identified the partitioning of evapotranspiration as one of six challenges for ecohydrologic research. That partitioning is important for physically based modeling of the soil water balance because the dynamics of the three component processes are very different - and hence respond to climate variability and change in different ways. Despite that fact, it is often lacking in many water balance models, particularly those designed for use in rainfall-runoff models. On the other hand, it is included in many soil-vegetationatmosphere transfer schemes (SVATS), which are generally designed for use as the land surface component of climate models. However, such models disagree widely as to the relative magnitude of each component. For example, a comparison study of 14 SVATS (Mahfouf et al., 1996) involved application of each model to a soybean crop in southwestern France over the five months of the 1986 growing season. For the 13 models that include it, soil evaporation as a percentage of total evapotranspiration ranged from $1.5 \%$ to $44 \%$. Furthermore, SVATs often show a strong dependence

Published by Copernicus Publications on behalf of the European Geosciences Union. 
of evapotranspiration partitioning on climate as controlled by differences in LAI (e.g., Choudhury et al., 1998; Lawrence et al., 2007). While this should clearly be the case with all else being equal (e.g., Schulze et al., 1994) it may not be for water-limited natural vegetation and rain-fed crops given that soil moisture is the main control on peak green LAI; even though greater energy for soil evaporation is available under conditions of low LAI, soil moisture is also generally low if the low LAI is due to aridity. It is quite possible then for both transpiration and soil evaporation to go to zero in near proportion to one another as the aridity of water-limited natural systems increases.

In this paper, we examine the role of vegetation density and the associated partitioning of evapotranspiration in the soil water balance over a domain encompassing the central United States using the Statistical-Dynamical Ecohydrology Model (SDEM) as coupled to the Shuttleworth and Wallace (SW, 1985) two-component canopy model (Kochendorfer and Ramirez, 2010). The SDEM is based on the seminal soil-vegetation-climate annual water balance model of Eagleson (Eagleson, 1978a-g). Enhancements to the original Eagleson model include implementation at the monthly time scale, separate root and recharge zones, frozen soil and snow accumulation and melt, and a more realistic representation of evapotranspiration partitioning. The latter is achieved by using separate rates of potential transpiration, potential evaporation for the soil surface and evaporation from canopy interception. All three rates are estimated using the SW model, which uses leaf area index (LAI) as the principal measure of vegetation density and subsequent control on conductance of the land surface to energy and water fluxes.

Kochendorfer and Ramirez (2010) apply the coupled SDEM and SW model to the estimation of the mean monthly water balance at two grassland sites in the US Great Plains. They find that the coupled model is able to match well the observed peak in green LAI by scaling a fixed phenology of LAI such that root-zone moisture, at its low point in August, just reaches the point at which the dominant grass species experiences water stress. They hypothesize that this may represent an ecologically optimal use of water, i.e., one that implies that the greatest reproduction is achieved through a balance of the likelihood of water stress and greater productivity. In this paper, we take a look at the use of the critical soil moisture level as a practical predictor of the peak in green LAI, rather than as a test of the ecological optimality hypothesis.

The coupled SDEM-SW model is applied at a half-degree resolution to the area of the United States bounded on the east and west by $87.5^{\circ} \mathrm{W}$ and $105^{\circ} \mathrm{W}$, and on the south and north by $32.5^{\circ} \mathrm{N}$ and $45^{\circ} \mathrm{N}$. That area encompasses most of the semi-arid Great Plains, plus more humid regions to the east. As humidity increases, factors other than water - namely light and nutrients - become more important in limiting plant growth. Nonetheless, in drier years water may be the most important factor in determining the peak in green LAI. In or- der to capture the impact of water availability on the interannual variability in vegetation density and evapotranspiration, we implemented the coupled model in a time series mode over the period 1951-1980. In each year, a monthly mean phenology of green LAI (i.e, a seasonal curve with a peak of one) was scaled by the same factor, up to a maximum of six, such that the critical soil matric potential (i.e., that at which the vegetation first experiences water stress) is just reached in the latter part of the growing season. To account for the interannual controls on plant growth, the peak in green LAI in a given year is limited to $\pm 50 \%$ of the 30 -yr mean. That percentage is based on the mapping of the interannual variation of grassland productivity over the US Great Plains by Sala et al. (1988). Although the above methodology ignores interannual variations in phenology and reproduces the interannual variability of peak green LAI to only a limited extent (Kochendorfer, 2005), we demonstrate below that it produces estimates of the long-term mean in peak green LAI at least as accurate as the NDVI-based estimates that provide the phenology. A fully dynamic vegetation model may produce even better estimates. However, our purpose here is to isolate the availability of soil moisture as a control on vegetation density and thereby inform the representation of soil-water dynamics in coupled hydrology and vegetation models. A more detailed discussion of the motivation for the ongoing top-down development of the SDEM can be found in Kochendorfer and Ramirez (2010).

\section{Overview of the statistical-dynamical ecohydrology model and its coupling to the Shuttleworth-Wallace canopy model}

Kochendorfer and Ramirez (2010) present in detail the formulation of the SDEM and SW model. Here we provide only a brief overview of the SDEM and its coupling to the SW model.

The SDEM is a one-dimensional representation of vertical soil-moisture dynamics as forced by the Poisson rectangular pulse (PRP) stochastic precipitation model and deterministic rates of potential evaporation from the soil surface, potential transpiration and evaporation from canopy interception. In the PRP model, a single interstorm/storm event is completely described by the time between storms, $t_{\mathrm{b}}$, the storm duration, $t_{\mathrm{r}}$, and the storm intensity, $i$. The storm depth, $h\left(=i t_{\mathrm{r}}\right)$, is also an important characteristic. $t_{\mathrm{b}}, t_{\mathrm{r}}$ and $i$ are assumed to be independent and well approximated by exponential distributions. $h$ is taken to be gamma-distributed for the sake of analytical tractability.

The potential rates of transpiration and evaporation and evaporation from canopy interception are calculated using the SW canopy model, which is a one-dimensional energy combination model, similar in form to the betterknown Penman-Monteith (PM) model (Monteith, 1965). Like the PM model, the SW model employs the concept of 
aerodynamic and surface resistances, but, unlike the single vegetated surface of the PM model, the SW model divides the land surface into a coupled, two-component system comprised of the soil surface and the vegetation canopy. The coupling occurs principally through the division of available energy between the two surfaces and the combination of the sensible and latent heat fluxes from the two surfaces at a hypothetical point of "mean canopy flow." The control that vegetation density exerts on the magnitude of the resistances and the partitioning of incoming energy is captured through the parameterization of those quantities as functions of leaf area index (LAI). The parameterizations are based on those in: Sellers (1965); Shuttleworth and Wallace (1985); Woodward (1987); Choudhury and Monteith (1988); Lafleur and Rouse (1990); and Sellers et al. (1996).

In the SDEM, infiltration and surface runoff during storms are modeled using a modified version of Phillip's (1969) approximate analytical solution of the concentration-dependent diffusion equation (i.e., the Richards equation) that makes use of the so-called time compression approximation (Eagleson, 1978e). The conceptual framework is as follows. Initially the intensity of rainfall is below the infiltration capacity of the soil. The infiltration capacity decreases as the soil profile becomes increasingly saturated and, at some point (referred to as the ponding time), may drop below the rainfall intensity, thereby producing infiltration-excess surface runoff.

Evaporation from the soil surface during inter-storm periods is modeled in a way analogous to infiltration: it proceeds at the constant potential rate as long as that rate is below the exfiltration capacity of the soil (typically referred to as stage-one or climate-controlled evaporation). As the soil profile dries, the exfiltration capacity decreases. At some point it may drop below the potential rate, thereby bringing the evaporation rate under the control of the availability of soil moisture (typically referred to as stage-two or soil-controlled evaporation).

In contrast to Eagleson's (1978d) assumption of a uniform sink, the SDEM incorporates root uptake of soil moisture into the Richards equation as a sink distributed exponentially through the root zone. The strength of that sink is equal to the potential transpiration rate as long as the matric potential in the root zone (as calculated from the monthly average soil moisture content) is above a critical value, $\Psi_{\text {uc }}$. Below that value it decreases linearly with moisture content to zero at the permanent wilting point, $\Psi_{\mathrm{lc}}$.

Using a derived-distribution approach, the onedimensional physical model is combined with the probability distributions of the stochastic precipitation model to arrive at expected values (i.e., means) of single storm and interstorm fluxes of infiltration and evaporation from the soil surface and from canopy interception. These values are then aggregated to monthly values by multiplying by the expected number of storms in the month. Percolation to groundwater is modeled as steady-state gravity drainage from the recharge zone. The movement of soil moisture between the root and recharge zones is governed by Darcy's Law for unsaturated flow and also assumed to be in steady-state at the monthly timescale.

\section{Application of the coupled models to the study region}

The predominant climatic feature of the Great Plains is a strong longitudinal gradient in annual precipitation superimposed on a latitudinal gradient in temperature. The study region also contains a wide range of soils and vegetation. The database of the Vegetation/Ecosystem Modeling and Analysis Project (VEMAP; Kittel et al., 1995), which covers the entire United States at a resolution of one-half of one degree, meets many of the data needs of the model. Specifically, it contains monthly climate variables over the period 1895-1993, as well as information on soils and vegetation types. Figure 1a depicts the average annual precipitation in the VEMAP database for the period 1951-1980 (as estimated by the Parameter-elevation Regressions on Independent Slopes Model; PRISM; Daly et al., 1994). Figure 1b depicts the average annual potential evapotranspiration (PET) as calculated with the SW model using the LAI values determined with the coupled models. We define PET as the sum of potential soil evaporation, potential transpiration and evaporation from canopy interception. As such it is not independent of either the type or the density (namely, LAI) of the vegetation. As compared to a reference-crop calculation of PET (such as Penman's (1948) original equation), the amounts in Fig. 1b cover a wider range, being greater (larger) in regions of small (large) LAI. The differences between annual average precipitation and PET (Fig. 1c) divide the study region longitudinally into dry and humid halves according to Thornthwaite's (1948) classification of climate.

The VEMAP vegetation types are depicted in Fig. 2. A mask of grid cells that are predominantly crops has been applied over the natural vegetation types. We also changed the natural vegetation class for a few cells to the dominant type of the surrounding cells in order to isolate individual vegetation classes to climatically similar regions. The dry half of the study region is dominated by grasses, savanna and shrubs, and the humid half by forests, savanna and crops.

The USDA soil texture classes based on grid-cell averages of sand, silt and clay percentages in the VEMAP database are shown in Fig. 3. The translation of those percentages to values of the soil hydraulic parameters is discussed in the Appendix. The Appendix also contains an overview of the development and use of a one-half-degree dataset of the parameters of the stochastic precipitation model from hourly observations, as well as a discussion of the source of the monthly climate variables. The discussion below is focused on the determination of a monthly phenology of LAI, the vegetation-specific parameters and the limited calibration of two of those parameters. 

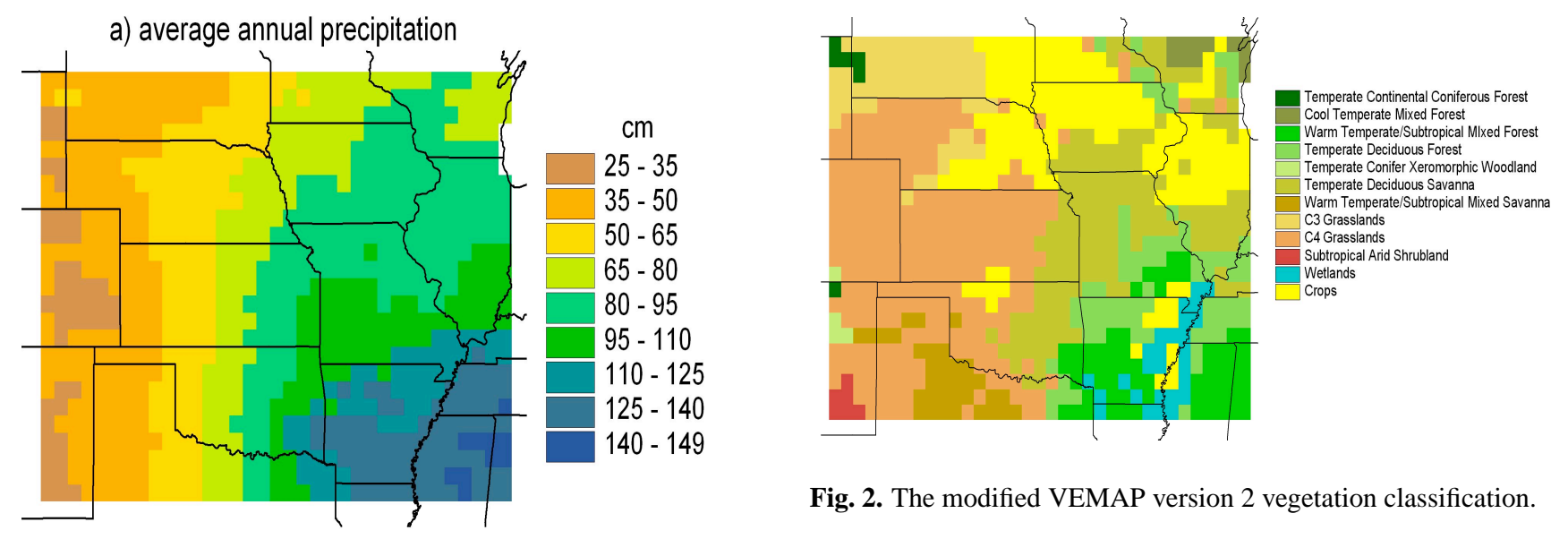

b) average annual potential evapotranspiration

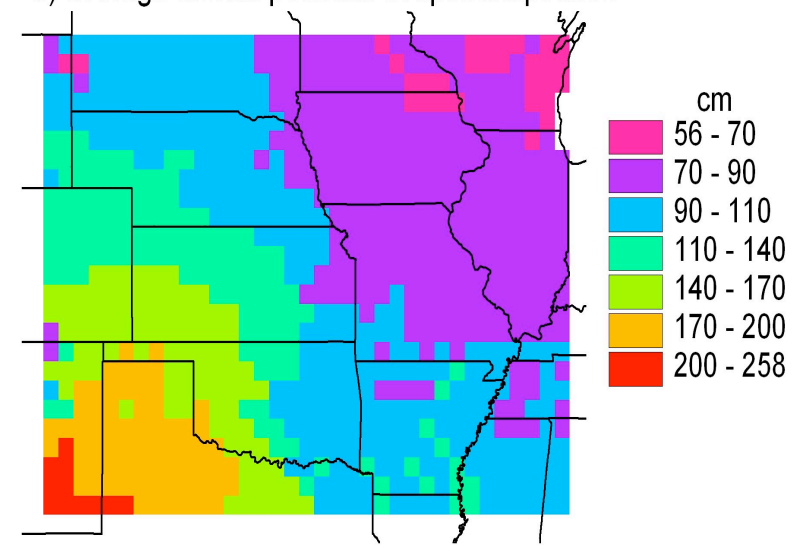

c) average annual precipitation surplus/deficit

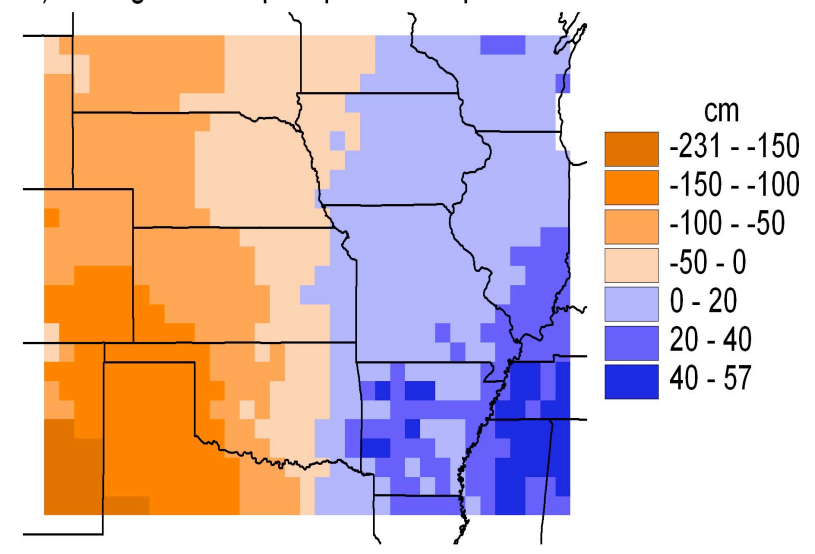

Fig. 1. (a) Average annual precipitation from the VEMAP/PRISM database, (b) average annual potential evapotranspiration calculated using model-maximized LAI, and (c) the difference (1951-1980).

\subsection{Green leaf area index}

To estimate the phenology of green LAI, we use the multiyear LAI dataset of Buermann et al. (2002), which was derived from the Normalized Difference Vegetation Index (NDVI) as measured by Advanced High Resolution Ra- 

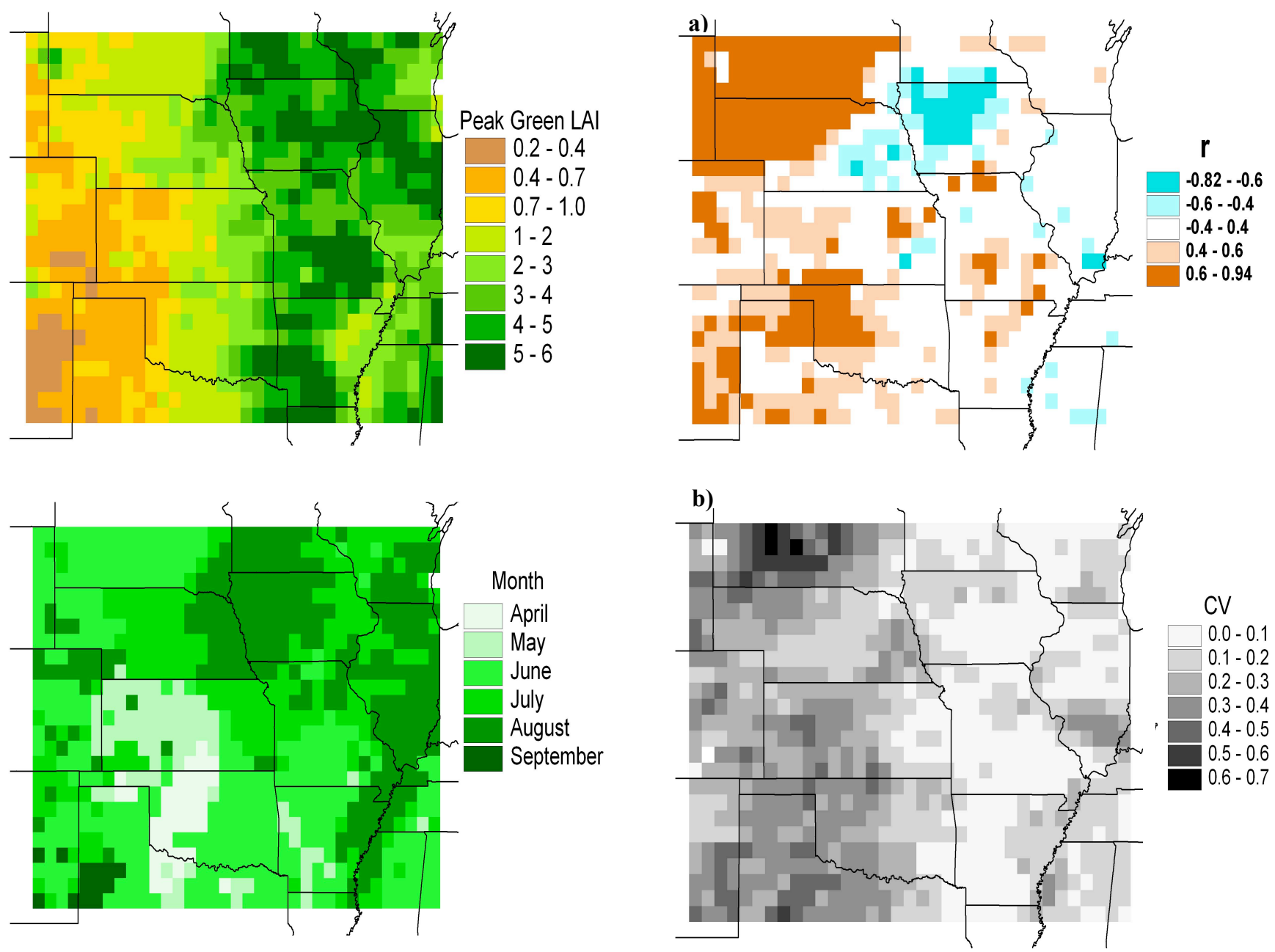

Fig. 4. Peak monthly average green LAI (July 1981-June 1991) and the month in which it occurs. From the AVHRR NDVI-based dataset of Buermann et al. (2002).

greater than 0.5. Over most of the rest of the study area, values are scattered both positive and negative. The exception is over the region of high crop density centered on west central Iowa (see Fig. 2), where the correlation is significantly negative. In their discussion of the interannual variability of crop production in Iowa, Prince et al. (2001) note that two of the lowest levels of NPP occurred during a year with a very wet spring and one with summer flooding. Therefore, the negative correlation in that area may indeed be a real phenomenon. In general, the lack of significant positive correlation over cropped areas highlights the importance of management factors, such as fertilization and irrigation, and climatic factors other than the availability of soil moisture. The low correlation and interannual variability in most of the humid half is likely due in part to the somewhat arbitrary upper bound of six in the observed LAI. For example, ground-based observations of LAI as high as 10 have been made at the Coulee Experimental Forest in southwest Wis-

Fig. 5. (a) Correlation between January-July precipitation and July LAI from the dataset of Buerman et al. (2002) from 1981 to 1990, and (b) The coefficients of variation for July LAI.

consin (Scurlock et al., 2001). Nonetheless, the correlation results over the humid half of the study region - along with the related fact that the coefficients of variation of observed LAI are generally low - suggest that it may be more appropriate to hold LAI at fixed values for crops and other vegetation for which water limitation is relatively unimportant on an interannual basis. However, the availability of water may still play a role in the long-term mean LAI of the vegetation in the humid half. The extent to which this is evident in model results is explored in Sect. 4.3.

\subsection{Parameter values specific to vegetation class}

Parameters values specific to each of the 12 VEMAP vegetation classes in the study region are listed in Table 1. Sources for parameter values are identified in the table and include other modeling studies, field studies and literature surveys. The precision applied to estimating a parameter value was 
Table 1. Parameter values of vegetation classes.

\begin{tabular}{|c|c|c|c|c|c|c|c|c|c|c|c|}
\hline \multicolumn{12}{|c|}{ Parameter Values Specific to Vegetation Class } \\
\hline Vegetation Class & $\begin{array}{r}\mathrm{z}_{\mathrm{u}} \\
(\mathrm{cm})\end{array}$ & $\begin{array}{r}\mathrm{z}_{\mathrm{d}} \\
(\mathrm{cm})\end{array}$ & $\begin{array}{r}r_{\mathrm{SS}} \\
\left(\mathrm{sm}^{-1}\right)\end{array}$ & $\begin{array}{r}\mathrm{r}_{\mathrm{smin}} \\
\left(\mathrm{sm}^{-1}\right)\end{array}$ & $\begin{array}{r}\mathrm{h}_{\mathrm{c}} \\
(\mathrm{m})\end{array}$ & $\begin{array}{r}\mathrm{w}_{1} \\
(\mathrm{~m})\end{array}$ & $\mathrm{f}_{\mathrm{d}}$ & $\mu$ & $\mathrm{n}_{\mathrm{e}}$ & $\begin{array}{r}\Psi_{\mathrm{uc}} \\
\left(10^{3} \mathrm{~cm}\right)\end{array}$ & $\begin{array}{r}\Psi_{\mathrm{lc}} \\
\left(10^{3} \mathrm{~cm}\right)\end{array}$ \\
\hline temperate continental coniferous forest & 120 & 200 & 150 & 600 & 10 & 0.001 & 0.2 & 0.50 & 4.0 & 3 & 15 \\
\hline warm temperate/ subtropical mixed forest & 100 & 200 & 225 & 500 & 10 & 0.04 & 0.2 & 0.60 & 4.0 & 2 & 15 \\
\hline temperate deciduous forest & 90 & 200 & 200 & 400 & 10 & 0.08 & 0.2 & 0.60 & 4.0 & 2 & 15 \\
\hline temperate conifer xeromorphic woodland & 90 & 200 & 150 & 600 & 7 & 0.001 & 0.2 & 0.50 & 4.0 & 5 & 20 \\
\hline $\mathrm{C}_{3}$ grasses & 50 & 100 & 125 & 250 & 0.5 & 0.01 & 0.3 & 0.45 & 2.0 & 10 & 25 \\
\hline $\mathrm{C}_{4}$ grasses & 50 & 100 & 100 & 400 & 0.5 & 0.01 & 0.3 & 0.45 & 2.0 & 10 & 25 \\
\hline subtropical arid shrubs & 130 & 200 & 50 & 400 & 1 & 0.01 & 0.2 & 0.50 & 2.0 & 15 & 30 \\
\hline wetlands & 70 & 150 & 75 & 350 & 1 & 0.02 & 0.2 & 0.60 & 3.0 & 5 & 15 \\
\hline crops & 70 & 150 & 100 & 325 & 1 & 0.02 & 0.1 & 0.65 & 2.5 & 5 & 15 \\
\hline references & 1 & & $2,3,4$ & $5,6,7$ & 11,12 & 11 & $2,12,13$ & 10,14 & 10,15 & $18,19,2$ & $21,22,23$ \\
\hline
\end{tabular}

parameter definitions:

$z_{\mathrm{u}}=$ depth of root zone,

$r_{\text {smin }}=$ minimum (i.e., unstressed) stomatal resistance,

$f_{\mathrm{d}}=$ ratio of persistent, non-transpiring LAI to peak green LAI,

$n_{\mathrm{e}}=$ eddy diffusion decay constant within a closed canopy, $z_{\mathrm{d}}=$ depth of recharge $z$ one,

$h_{\mathrm{c}}=$ canopy height,

$\mu=$ Beer's Law extinction coefficient,

$\Psi_{\mathrm{uc}}=$ critical root-zone matric potential,
$r_{\mathrm{Ss}}=$ soil surface resistance,

$w_{1}=$ leaf width,

and $\Psi_{\mathrm{lc}}=$ critical leaf water potential. references:

1. Jackson et al. (1996),

4. Bond and Willis (1969),

7. Running and Hunt (1993),

10. Jarvis et al. (1976),

13. Hazlett (1992),

16. Ripley and Redmann (1976),

19. Newman (1969),

22. Gardner and Ehlig (1963),

25. Boyer (1971),

28. Federer (1979),

\author{
2. Sellers et al. (1992), \\ 5. Korner et al. (1979), \\ 8. Rutter (1975), \\ 11. Sellers et al. (1996), \\ 14. Ross (1975), \\ 17. Rauner (1976), \\ 20. Hellkvist et al. (1973), \\ 23. Gardner (1960), \\ 26. Denmead and Shaw (1962), \\ 29. Havraneck and Benecke (1978).
}

\author{
3. Camillo and Gurney (1986), \\ 6. Woodward (1987), \\ 9. Nielson (1995), \\ 12. Dickinson et al. (1993), \\ 15. Denmead (1976), \\ 18. Cowan and Milthorpe (1968), \\ 21. Richter (1976), \\ 24. Sala et al. (1981), \\ 27. Gollan et al. (1986),
}

a function of the availability, range and uncertainty of values in the literature, as well as of the sensitivity of model results to the given parameter. Many values, such as canopy height and leaf width, are only order of magnitude estimates. Careful consideration was given to the monthly timescale at which the model is implemented, especially with regard to $r_{\text {smin }}$, the minimal stomatal resistance. In selecting parameter values, we also considered the degree to which vegetation classes other than the designated one are present. For example, much of the area parameterized as wetland and temperate deciduous savanna is cultivated cropland. Calibration was performed for the values of only two parameters: $r_{\text {smin }}$ and $r_{\mathrm{ss}}$, the soil-surface resistance. In initially estimating values of $r_{\mathrm{ss}}$, we took the view that they are mainly due to the litter layer. The calibration process consisted mainly of visually matching modeled mean annual runoff to contours of observed streamflow. Additional consideration was given to reproducing the observed peaks in green LAI. The values of $r_{\text {smin }}$ and $r_{\text {ss }}$ were kept well within their range of uncertainty, and their original rank by vegetation class was preserved. In this way, the impact of uncertainties in the relative magnitude of the parameters on the partitioning of evapotranspiration was kept to a minimum. Sensitivity analysis with various combinations of $r_{\mathrm{smin}}$ and $r_{\mathrm{ss}}$ that reproduce similar peak LAI and total evapotranspiration showed the conclusions of this paper to be robust.

As the main determinant of the absolute amount of water available for transpiration, the root zone depth, $z_{\mathrm{u}}$, is one of the more important parameters in SVAT models (Jackson et al., 2000; Mahfouf et al., 1996). The distribution of roots below a given stand of vegetation is a complex function of plant speciation and phenology, chemical and physical properties of the soil, and climate. Many of those factors converge to produce similar root distributions within a given biome (Schenk and Jackson, 2002). Jackson et al. (1996) compiled a database of 250 root studies, which they grouped 
into 11 biomes. They fit an exponential equation to plots of cumulative root fraction versus soil depth within each biome. We used the resulting decay constants to calculate root zone depth as the depth that contains $95 \%$ of the root biomass. Because temperate savanna and wetlands are not amongst the biome classes used by Jackson et al. (1996), we selected values intermediate between grasses and forests. Likewise, the root zone depth of conifer woodland was taken as intermediary between that of savanna and forest.

Evapotranspiration estimates with the model are much less sensitive to the depth of the recharge zone, $z_{\mathrm{d}}$, which mainly controls the phase and amplitude of the annual cycle in groundwater recharge. A recharge zone of about twice the depth of the root zone gave seasonality in groundwater recharge (and hence base flow) consistent with the observed seasonality in streamflow across the study region (e.g., Geraghty and Miller, 1973). Accordingly, values for $z_{\mathrm{d}}$ of 100, 150 and $200 \mathrm{~cm}$ were assigned to vegetation classes based on the closest match to twice the corresponding value of $z_{\mathrm{u}}$.

As the determinant of the moisture content at which transpiration begins to decrease below the potential rate (and consequently a determinant of the peak in green LAI), the critical soil matric potential, $\Psi_{\mathrm{uc}}$, is also a relatively important parameter. That such a point exists is based on a resistance model of transpiration typically attributed to Cowan (1965), following the work of Gardner (1960) and van den Honert (1948). The model indicates that $\Psi_{\text {uc }}$ should be a function of the transpirative demand of the atmosphere, as well as the density of the roots and of the transpiring leaf area. Rather than try to estimate the resistances in the Cowan model, we assume that $\Psi_{\mathrm{uc}}$ is relatively invariant within given climatic regions and associated vegetation classes at the time of the year when water stress is most likely to occur. Assuming fixed values of $\Psi_{\mathrm{uc}}$ is fairly common in the modeling of transpiration (Guswa et al., 2002).

\section{Results and discussion}

As noted above, we calibrated the soil surface resistances and minimum stomatal resistances of the SW model by vegetation class via a visual fit of modeled mean annual runoff to contours of observed streamflow. Because the streamflow contours were developed as an average for the period 19511980 (Gebert et al., 1987), we used that 30-yr period. No separate validation period is examined. Rather, the validity of the model is established through the realism with which it reproduces not only runoff but also all other components of the water balance, including soil moisture, green LAI, soil evaporation and transpiration.

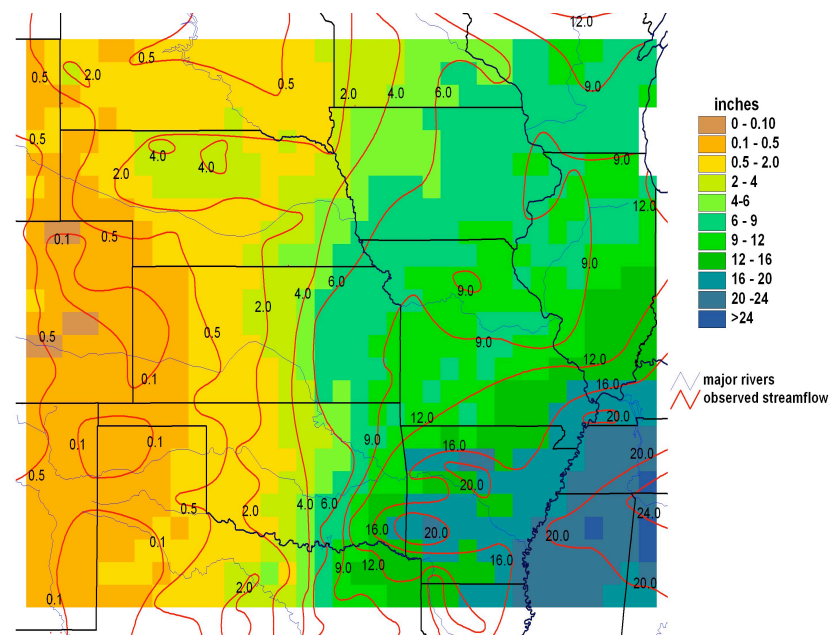

Fig. 6. Comparison of modeled annual average total runoff with observed streamflow (1951-1980). Streamflow contours are from Gebert et al. (1987).

\subsection{Annual runoff}

The contours of observed streamflow overlay modeled annual runoff in Fig. 6. An excellent match to overall climatic trends was obtained. Remarkably, the model even does a reasonable job of capturing the higher runoff over the topographically complex Black Hills and Ozark Mountains based on grid-cell average climate alone. Nonetheless, for a number of individual cells and small clusters of cells with runoff greater than two inches, differences between the contours and model results are as high as about $\pm 50 \%$. In addition, on a relative basis, the model overestimates streamflow over most of the driest part of the study region (i.e., New Mexico and the Texas and Oklahoma panhandles.) This is likely due to an overestimate in surface runoff in the region (Kochendorfer, 2005). Many other reasons could be cited for the differences between observed stream flow and modeled runoff. Some of the most significant not associated with measurement and interpolation error in the contours, nor with error in the water balance model, have to do with scale and the fact that runoff calculated from streamflow may not necessarily be representative of actual watershed runoff. In general, the one-dimensional form of the SDEM and its lack of interaction with groundwater is a significant limitation to predicting runoff and streamflow at basin scales. However, our main interest in comparing modeled runoff and observed streamflow is as a validation of modeled evapotranspiration for a typical upland site within each grid cell. In that context, we can assess the model as performing very well.

\subsection{Soil moisture}

We identified four sets of long-term records of observed soil moisture encompassing a range of climatic conditions 


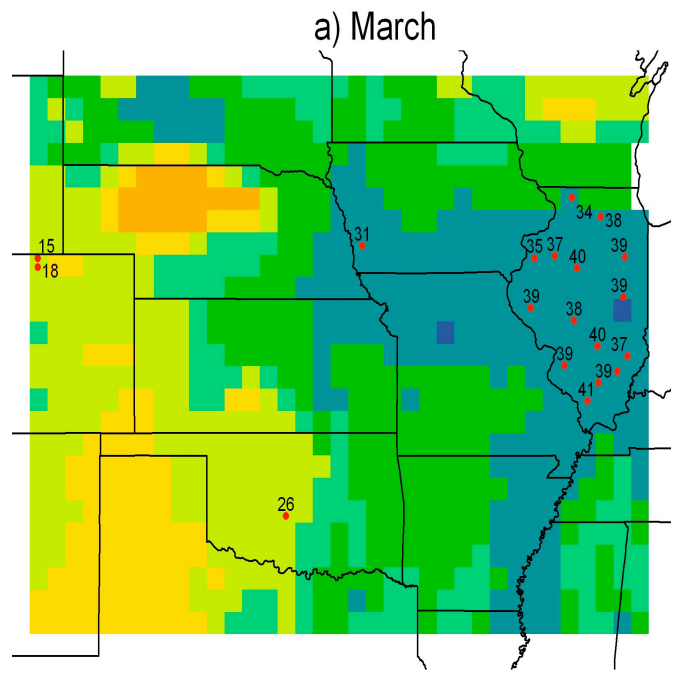

percent

$5-10$

$10-15$

$15-20$

$20-25$

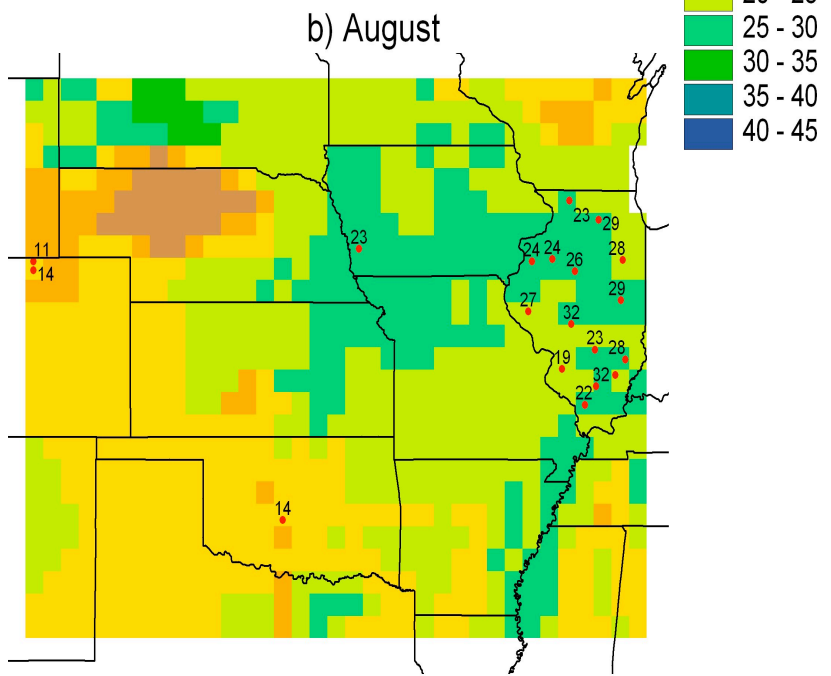

Fig. 7. Comparison of modeled (1951-1980) and observed (various record lengths) average volumetric soil moisture in the root zone: (a) March and (b) August. Observations are the red dots.

across the study region. The first two datasets come from two grassland sites in the Great Plains: the Central Plains Experimental Range (CPER) in north-central Colorado and the USDA-ARS R-5 experimental watershed near Chickasha, Oklahoma. Those two sites are used by Kochendorfer and Ramirez (2010) to test the LAI-optimization hypothesis with the coupled models. The third set of soil moisture data comes from another USDA-ARS experimental watershed: an 83-acre cropped watershed near Treynor, Iowa, designated as W-2. The collection of soil moisture data from W-2 lasted from 1972 until 1994. Those data, as well as the fourth dataset, were downloaded from the Global Soil Moisture Data Bank (Robock et al., 2000). The fourth and final set of soil moisture data is from the Illinois Climate Network (Hollinger and Isard, 1994). We used the data from 1983 to 2001 for 15 soil-moisture stations that are grass covered and located in the silt loam and silty clay loam soils that dominate the state. The soil textures and vegetation at the other locations were also similar to the soil textures and vegetation classes assigned to the corresponding grid cells. Although comparison of site-specific soil moisture data with grid cell calculations can be problematic, such a comparison may provide an indication whether large-scale variations in soil moisture are reproduced by the model.

The observations of mean root-zone (as defined by the values of $z_{\mathrm{u}}$ in Table 1) volumetric soil moisture over the given periods of record are plotted on top of model results in Fig. 7 for March (with the exception of the Iowa site, for which April is plotted due to the lack of March measurements) and August. Those months are the respective months in which modeled soil moisture most frequently reaches its annual maximum and minimum. Based on the plots, largescale variations in the magnitude and seasonality of moisture content appear to be captured by the model. The influence of soil texture is seen throughout the study region, mostly noticeable in the differences in moisture content between the Sand Hills of north-central Nebraska and the Pierre Shale Plains of south-central South Dakota. In the CPER observations, the significance of subgrid variability in soil texture is seen in the higher moisture retention of the clay-loam soil in comparison to the sandy-loam soil (where the latter has been plotted above the former). Over Illinois, there is no clear spatial structure to either observed or modeled soil moisture. Apparently, the slight north-to-south increase in annual precipitation over Illinois is more-or-less completely offset by the north-to-south increase in potential evapotranspiration. For both March and August, using the t-test for unequal variances, there is no significant difference at the 95\% confidence level between the mean of the 15 observed values and the mean of modeled values for the grid cells in which the observations fall. Finally, we note that in contrast to that for the two grassland sites, modeled mean August soil moisture values for the Iowa and Illinois sites are somewhat above the critical value, indicating that in many years the model reaches the maximum peak green LAI of six.

\subsection{Model-determined leaf area index and above-ground net primary productivity}

Figure 8 depicts the 30-yr averages of model-determined peak green LAI and compares them to the unaltered NDVIbased observations. The model-determined LAI preserve the general climatic trend of increasing LAI with increasing humidity, while largely missing more regional-scale variations. The model-determined LAI tend to be higher than the unaltered observations in the drier regions and lower in the wetter regions. As a whole, the model-determined LAI, with a mean of 2.79 and standard deviation of 1.61 , tends to be slightly larger and slightly less variable than the unaltered observations, which possess a mean of 2.66 and a standard deviation of 1.78. Given the uncertainties in the NDVI-based 
a) maximized peak green LAI

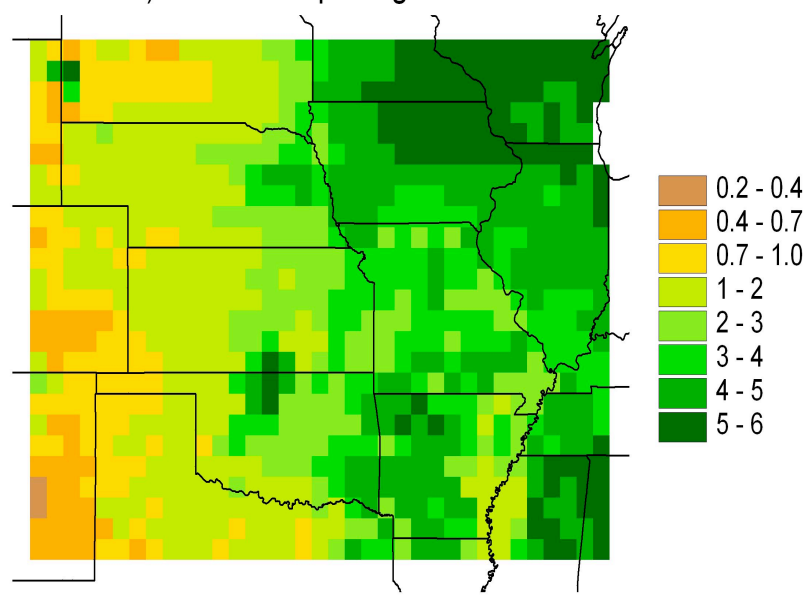

b) ratio to unaltered observations

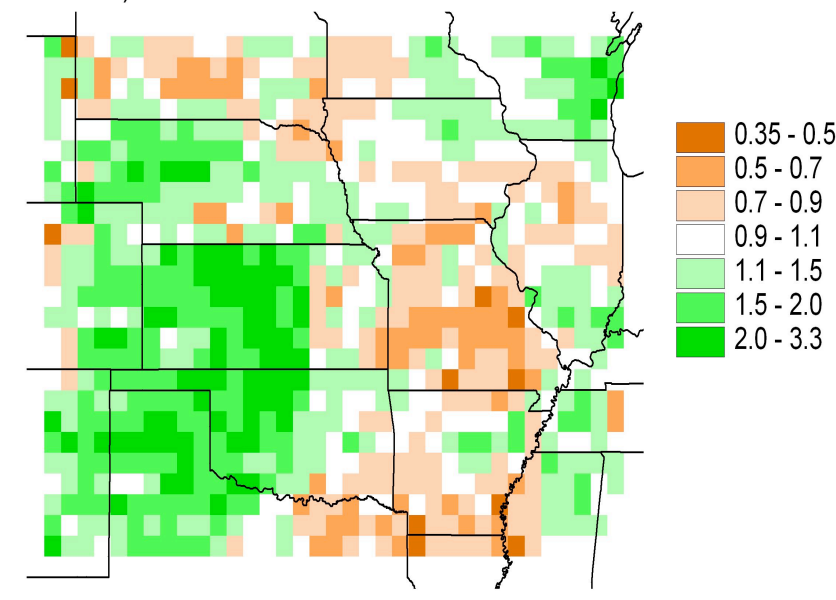

Fig. 8. (a) Average peak in model-determined green LAI (19511980), and (b) its ratio to the average NDVI-based estimates (19811991) of Buerman et al. (2002).

observations discussed in Sect. 3.4, we cannot assume that the unaltered observations are a more accurate representation of actual LAI. Using ground-based observations and productivity data, we examine below the likely accuracy of the model-determined LAI as compared to the unaltered observations, mainly focusing on the grassland region and then briefly on the more humid half of the study region.

As seen in Fig. 8b, the model-determined LAI are greater than the unaltered observations over most of the grassland region. The area of greatest disagreement is centered midway along the border between Nebraska and Oklahoma. The dataset of Scurlock et al. (2001) contains ground-based LAI measurements at two sites within this area. The first is an LAI of 7.5 for a 1997-1998 harvest of a wheat crop located at $36.75^{\circ} \mathrm{N} 97.08^{\circ} \mathrm{W}$. For the corresponding grid cell, which is parameterized as $\mathrm{C}_{4}$ grasses, the model-determined LAI is 5.9, indicating that for most years the upper bound of 6.0 is reached. In contrast, the unaltered NDVI-derived peak in green LAI is only 2.1. The second site is located in the adjacent grid cell to the east at $36.85^{\circ} \mathrm{N} 96.68^{\circ} \mathrm{W}$. The vegetation there is reported as grass, with two undated LAI measurements of 5.4 and 5.8. For the grid cell, the model-determined LAI is 2.1 , and the unaltered NDVI-derived peak is 1.9. We suspect that the field measurements are biased towards the high side, but nonetheless, they suggest a region of higher productivity. Also indicative of the potential for higher productivity is the fact that a group of seven cells just to the west of the field measurements are mostly in crops (see Fig. 2). Located at the southern end of the area of higher modeldetermined LAI, at $35.15^{\circ} \mathrm{N} 97.75^{\circ} \mathrm{W}$, is the R-5 experimental watershed. For this grassland catchment, two hydrologic modeling studies were found that use field-based estimates of peak green LAI of 2.5 (Ritchie et al., 1976) and 3.2 (Luxmoore and Sharma, 1980). For the corresponding grid cell, the model-determined LAI is 2.1, and the unaltered NDVIderived observation is 1.1 - further evidence that the latter underestimates peak green LAI in this area of the grasslands.

Given the paucity of field-measured LAI, we turn to another measure of vegetation density, aboveground net primary production (ANPP). Specifically we rely on ANPP estimates for the grassland region made by Tieszen et al. (1997), who correlated potential rangeland production estimates with NDVI data from 1989 to 1993 . In Fig. 9a, the modeldetermined peak in green LAI values for those cells designated as grassland in the model parameterization are plotted against the corresponding Tieszen et al. (1997) estimates of ANPP (as resampled to the half-degree grid by Zheng et al., 2003). The unaltered observations of peak-green LAI are plotted against the ANPP estimates in Fig. 9b. Based on a power curve fit, the ANPP data is substantially more correlated to the model-determined LAI $\left(R^{2}=0.59\right)$ than to the unaltered observations $\left(R^{2}=0.42\right)$. We note that both the LAI observations and the ANPP estimates are derived from the NDVI data - albeit in very different ways. For this reason, the higher correlation between LAI and ANPP brought about by the model is a particularly strong endorsement of the LAI optimization process for water-limited grasslands.

The most distinct exceptions to the trend in the grasslands region of a model-determined LAI larger than the unaltered observations are the high-clay-content regions of the Pierre Shale Plains and east-central Texas (see Fig. 3). In contrast to the Pierre Shale Plains, where the grid cells contain the highest percentages of clay within the larger study region, the Sand Hills region is the locus of the highest percentages of sand. Over the entire Sand Hills region the modeldetermined LAI are larger than the observations, with the ratio greater than two for a few of the cells. The contrast in model-determined LAI between the two regions is reflected in the Tieszen-et-al. ANPP data; in the Pierre Shale Plains, ANPP generally falls in the range of 60 to $110 \mathrm{~g} / \mathrm{cm}^{2}$, while in the Sand Hills, it generally falls in the range of 120 to $170 \mathrm{~g} / \mathrm{cm}^{2}$ (see Fig. 12b for a plot of the total NPP 

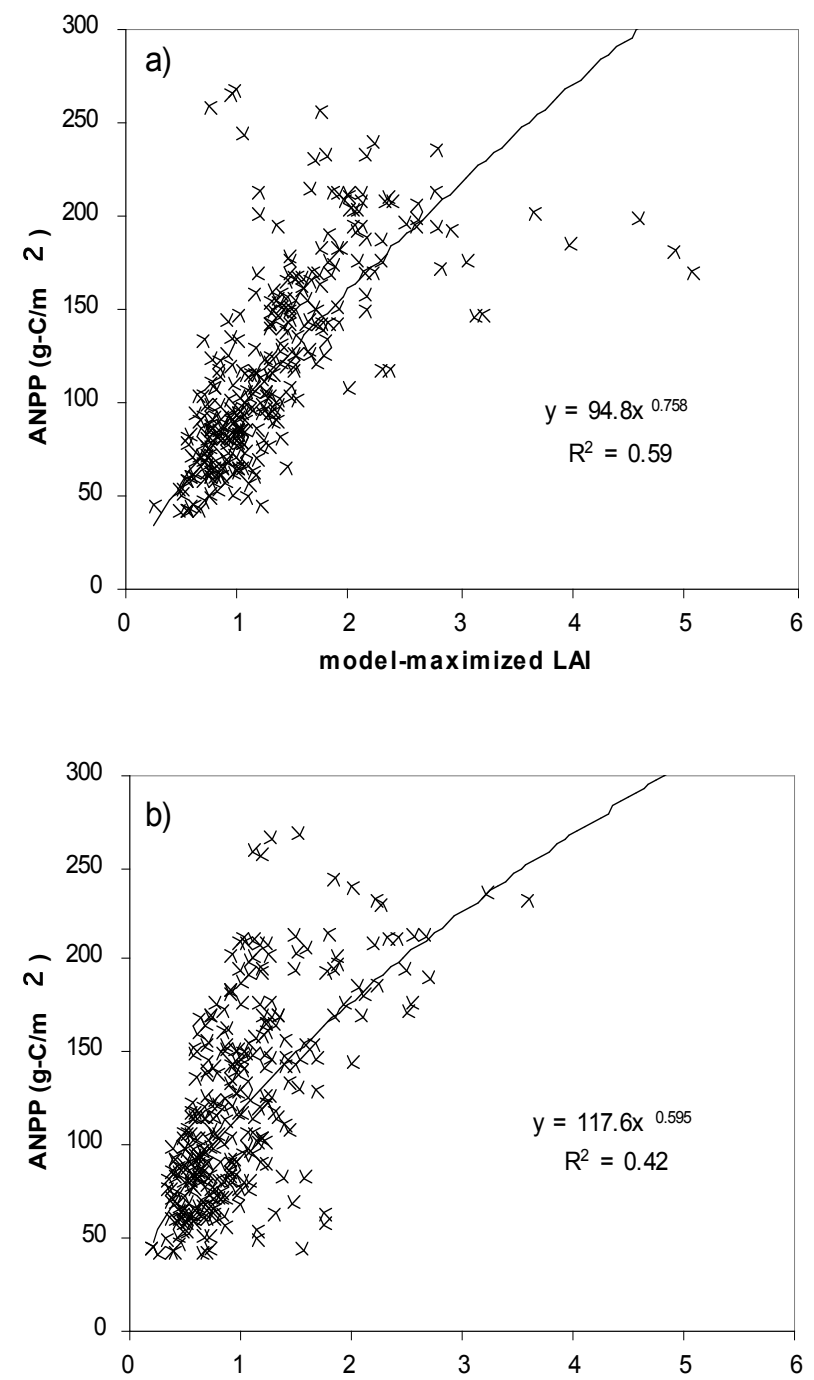

Fig. 9. Comparison of the estimates of grassland ANPP from Zheng et al. (2003) based on Tieszen et al. (1997) with: (a) modeleddetermined peak green LAI, and (b) unaltered NDVI-based observations of peak green LAI (Buerman et al., 2002).

data, which are derived from the ANPP data.) The modeldetermined LAI in the corresponding grid cells range from 0.7 to 0.9 and 1.3 to 1.9 , respectively - the same approximate one-to-two ratio as ANPP. In contrast, the unaltered observations of peak green LAI (see Fig. 8) are actually higher over the Pierre Shale Plains than over the Sand Hills. That the model reproduces the higher productivity of the Sand Hills suggests that it is able to capture the inverse texture effect (Noy-Meir, 1973). Kochendorfer and Ramirez (2010) evaluate that ability more rigorously using model results for the CPER site and the R-5 watershed.

We cannot compare the model-determined LAI against the unaltered observations without addressing the impact of land use. Grazing is the predominant land use in the grasslands region. The significance of grazing intensity can be seen in comparison of the R-5 catchment, which was moderately grazed, with the adjacent R-7 catchment, which has similar soils but was intensely grazed. As a result of the overgrazing and subsequent erosion, the vegetation cover was significantly smaller over the R-7 catchment; Ritchie et al. (1976) indicate a peak green LAI value of 0.5 for the R-7 catchment, and Luxmoore and Sharma (1980) report a value of 0.75 . The model-determined LAI may thus be more representative of a "potential" LAI, which would be achieved in the absence of overgrazing, fire, infestation, disease or other significant disturbances (e.g., Nemani and Running, 1995). At least some of the difference between the model-determined LAI and the unaltered observations over the grasslands is then attributable to one or more of those disturbances, grazing being the most likely culprit on a long-term basis.

Second in importance in the grasslands to grazing is crop production. While only a handful of cells within the grassland region are designated as crops in the model parameterization, crops are raised throughout. For example, the April and May peak in green LAI over much of the central and southern grasslands (see Fig. 2) is an indication of the prevalence of winter wheat there. Because it occurs when transpirational demand is still relatively low, the early peak in fact allows for the relatively high model-determined LAI in this region. The model-determined LAI may thus be more representative of wheat than the more predominant grasslands. On the other hand, management factors, such as fertilizer application and irrigation, likely play a role in the modeldetermined LAI underestimating the observed grid-cell averages. In fact, many of the cells in the grassland region where the model-determined LAI is less than the unaltered observations correspond to areas of high levels of irrigation (USGS, 1993).

Over the humid half of the study area, the differences between the model-determined peak in green LAI and the unaltered observations show some spatial structure (Fig. 8b). The greatest association with vegetation type or soil texture is a low bias in the model-determined values in lower Mississippi River valley, which is dominated by crops and wetlands over silty clay loam soils (see Figs. 2 and 3). We were unable to find ground based observations of LAI in this region. Both raw NDVI data and the unaltered NDVI-based LAI observations in Fig. 4, show it to be a region of lower productivity. However, actual mean peak LAI may not be as low as the 1-2 range predicted by the model, indicating that the soil hydraulic parameters or the critical matric potential for crops and wetlands, or both, may produce a higher than actual value of the critical soil moisture content. Additionally, as for the grassland region, crop management factors may play a role in the actual LAI being greater than the modeled.

The difference between modeled and observed peak LAI in the humid half of the study region is relatively unbiased in the mean. Rather than being an endorsement of the ecological optimization hypothesis, this is most likely due to the upper bound being 6 in both the model and the NDVI-based 

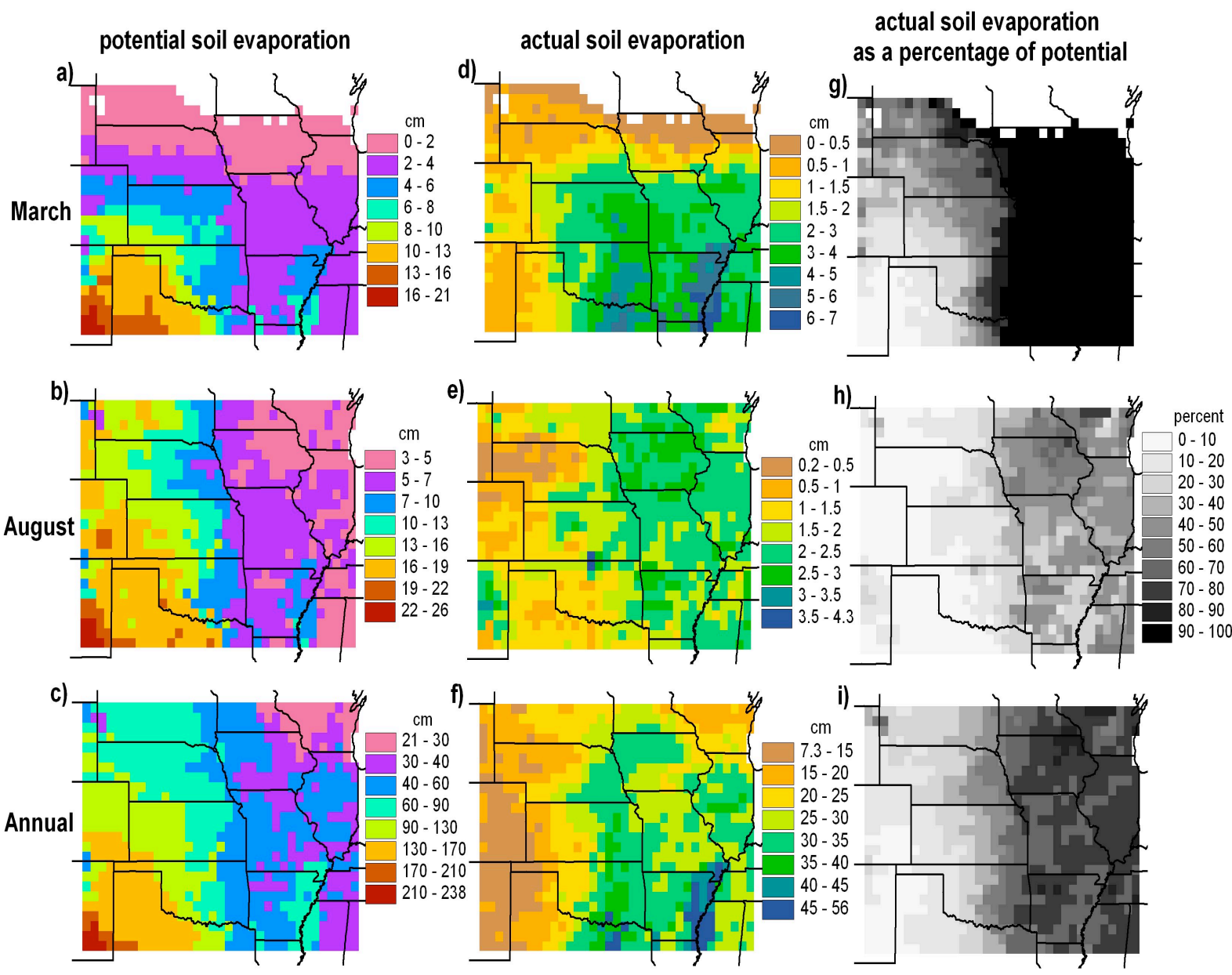

Fig. 10. Average potential soil evaporation, actual soil evaporation and actual as a percentage of potential for March, August and the entire year (1951-1980).

observations. Therefore, we cannot conclude that the use of the critical matric potential to estimate peak green LAI during years in which water may be limiting improves the unaltered NDVI-based observations in the humid half of the study region. On the other hand, evidence presented above for the grassland regions strongly suggests that the ecological optimality hypothesis is a practical means for estimating the peak in green LAI for these systems in the absence of significant disturbance to their natural productivity.

\subsection{Potential and actual soil evaporation}

Results from application of the SW model to the calculation of potential rates of soil evaporation with model-determined LAI are depicted in Fig. 10a-c for March, August and for the sum of all months. The results for March, when green LAI is low or nonexistent, are primarily controlled by the latitudinal temperature gradient. The results for August, being higher in areas of lower LAI, are indicative of the growing season (see Fig. 8a). Because evapotranspiration takes place predominantly in the growing season, a similar pattern is seen for the annual totals. Actual soil evaporation is depicted in Fig. 10d-f as depths, and in Fig. 10g-i as a percentage of the potential. In the humid half of the study region in March, soil evaporation is virtually always under climate control (i.e., stage-two evaporation is seldom reached) as a result of the seasonally high moisture content and low potential soil evaporation. As one moves to the southwestern corner, the degree of soil control rapidly increases to the point of being almost entirely limited by the availability of soil moisture (i.e., stage-two evaporation is reached soon after the end of storms.) In August, when potential rates are at or near their highest and soil moisture values at their lowest, most of the dry half of the study region undergoes strongly soil-moisture-limited evaporation.

Figure 11 depicts total evapotranspiration and the percentage that is soil evaporation for July and for the entire year. The remaining percentages are dominated by transpiration, with canopy interception accounting for no more than about $10 \%$ on both a seasonal and annual basis. In July, when green 


\section{total evapotranspiration}
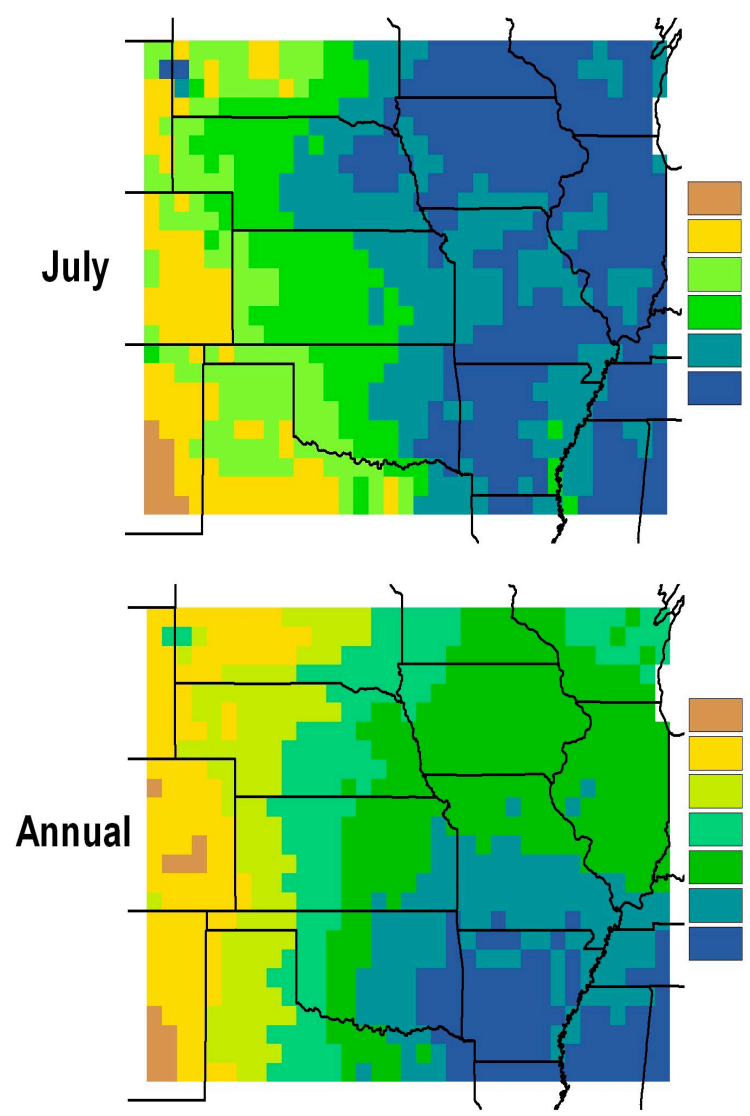

\section{soil evaporation as a percentage of total evapotranspiration}

$\mathrm{cm}$

$3.4-5$

$5-6.5$

$6.5-8$

$8-10$

$10-12$

$12-14$

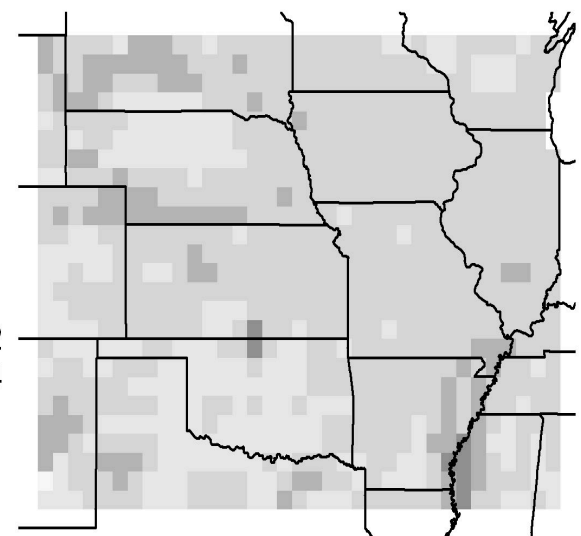

percent

$0-10$

$10-20$

$20-30$

$30-40$

$40-50$

$50-60$

$60-70$

$70-80$

$80-90$

$90-100$

Fig. 11. Average total evapotranspiration and soil evaporation as a percentage of total evapotranspiration for July and the entire year (1951-1980).

LAI is at or near its peak, soil evaporation falls in the range of $10 \%$ to $30 \%$ of total evapotranspiration for the majority of the cells, with the percentages being more variable in the dry half of the study region. On an annual basis, soil evaporation comprises between $30 \%$ and $60 \%$ of total evapotranspiration for nearly all the cells. The distribution of percentages shows surprisingly little correlation to vegetation class or climate. This suggests that the generally lower vegetation cover and lower soil-surface resistances in the dry half of the study region are more-or-less completely offset by the drier soil.

In contrast to vegetation class and climate, the influences of soil texture are clear in the percentages in Fig. 11. The differences in LAI resulting from the differences in soil texture between the Pierre Shale Plains and the Sand Hills manifest themselves as, respectively, regionally higher and lower percentages of soil evaporation. In the humid half of the study region, the highest percentages of soil evaporation (i.e., those in excess of 60\%) are associated with the high-clay soils of the lower Mississippi River valley and Northeast Texas (see Fig. 3). The proximate cause of the higher percentages in regions of high clay content is the greater potential soil evap- oration (see Fig. 10b, c) that results from the regionally lower LAI (see Fig. 8a). If we look at soil evaporation as a percentage of potential soil evaporation (see Fig. $10 \mathrm{~g}-\mathrm{i}$ ), we see that the percentages are slightly higher than the surrounding cells in the high clay areas of the humid half, while slightly lower in the Pierre Shale Plains. This suggests that the lower diffusivity of the high-clay soils has a greater offsetting effect to the higher moisture content in the Pierre Shale Plains than in the humid regions. The difference has mainly to do with the degree to which soil evaporation is controlled by moisture content; in the humid half of the study region, at least $60 \%$ of the potential demand is met for nearly all the cells on an annual basis.

Although relatively new isotopic, sap-flow and eddycovariance methods are increasingly being applied (e.g., Smith and Allen, 1996), separate observation of soil evaporation and transpiration has historically been difficult, and continues to be, particularly at the stand and larger scales, and over time periods representative of average climatic conditions. Therefore, there are not many data that can be used to validate the partitioning of evapotranspiration in the 
a) average annual transpiration

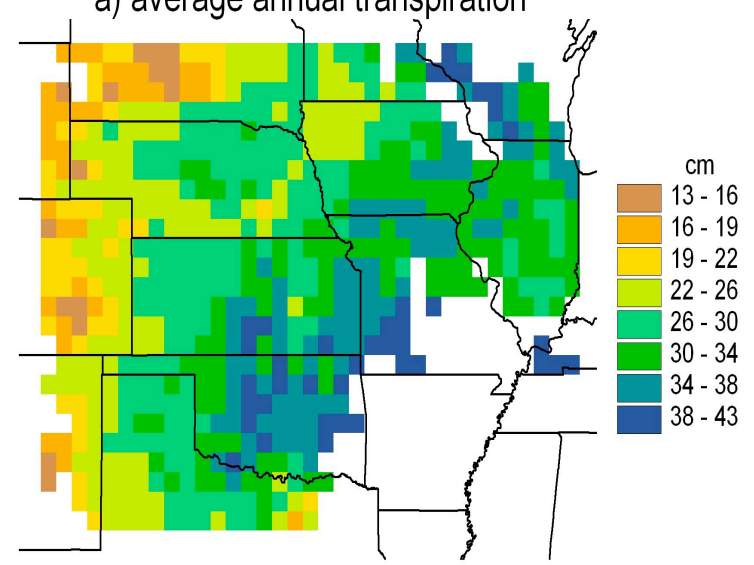

b) total net primary productivity

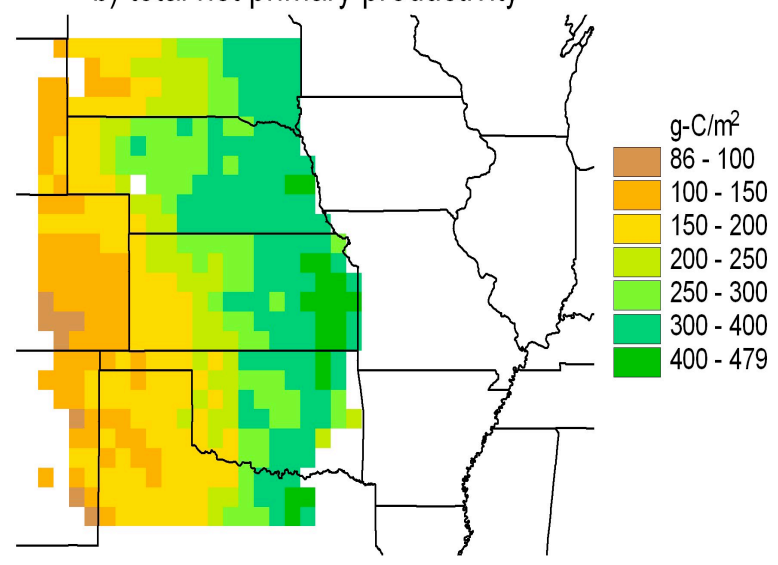

c) water use efficiency
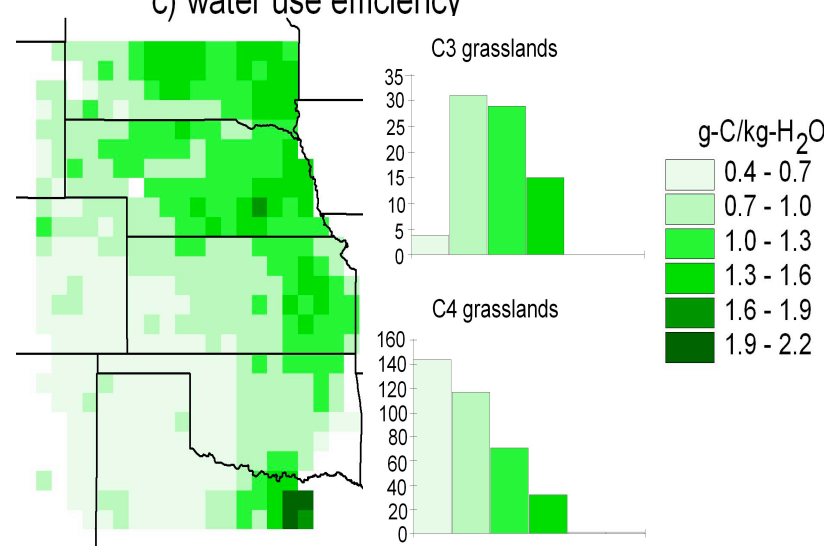

Fig. 12. (a) Modeled average annual grassland transpiration (19511980) for cells in which the natural vegetation is grassland or savanna, (b) estimates of average annual TNPP (1989-1993) from Tieszen et al. (1997) as contained in the database of Zheng et al. (2003b), and (c) water use efficency calculated with (a) and (b). model results. Nonetheless, a few studies were identified at sites in or near the study region. Of particular interest are the stable isotope study of Ferretti et al. (2003) and the energy-balance measurement and modeling study of Massman (1992) conducted at the CPER. Those studies were reviewed by Kochendorfer and Ramirez (2010) and found to be in good agreement with model results for the CPER. Their SDEM-SW results show that, over the growing season, soil evaporation is the dominant component of evapotransiration in April and May and a neglible component in August and September, with the June and July percentages approximating the average over the whole growing season. Even in the sparse canopy of the shortgrass steppe - measured peak LAI at the CPER ranges from 0.4-0.6 (Hazlett, 1992; Knight, 1973), growing-season soil evaporation appears to average one third or less of total evapotranspiration. Measurementbased studies from more arid environments in the southwest USA (Dugas et al., 1996; Stannard and Weltz, 2006) indicate that transpiration dominates there as well.

In comparison, to natural vegetation, more evapotranspiration partitioning studies have been conducted of crops, with a tendency to focus on irrigated systems. The cumulative impression from several such studies (Ashktorab et al., 1994; Klocke, 2003; Leuning et al., 1994; Massman and Ham, 1994; Peters and Russell, 1959; Villabalobos and Fereres, 1990), as well as from a review paper (Burt et al., 2005), is that cumulative growing-season soil evaporation ranges from $20 \%$ to $50 \%$ of total evapotranspiration for wellwatered crops - both irrigated and rain-fed. Thus crop percentages in the literature are similar to those for semi-arid grasslands and also in good agreement with the model results in Fig. 10 (which were produced under the assumption of rain-fed crops.) Variations in the literature values appear to be more dependent on irrigation and tilling schemes than on climate or crop type.

Finally, we consider the empirical data on evapotranspiration partitioning in forests in the humid half of the study region. Eddy covariance measurements in deciduous forests just east of our study region (Grimmond et al., 2000; Wilson et al., 2001) show evaporation from the forest floor to be about $10 \%$ of total evapotranspiration at peak LAI. Because model results in Fig. 13 show a contribution in July from soil evaporation of $10-30 \%$, we can conclude that the model tends to overestimate soil evaporation in humid forests. This may be the result of the upper bound on LAI being limited to six. Another possible source of model error is the values of surface soil resistance for forests in Table 1 underestimating the mulching effect of the litter layer. In general, greater consideration needs to be given to the limitations of applying the two-component SW model (which was originally developed for sparse crop canopies) to the taller and generally heterogeneous, multi-leveled canopies of forests, woodlands and savannas. 
a) residual moisture content, $\theta_{\mathrm{r}}$

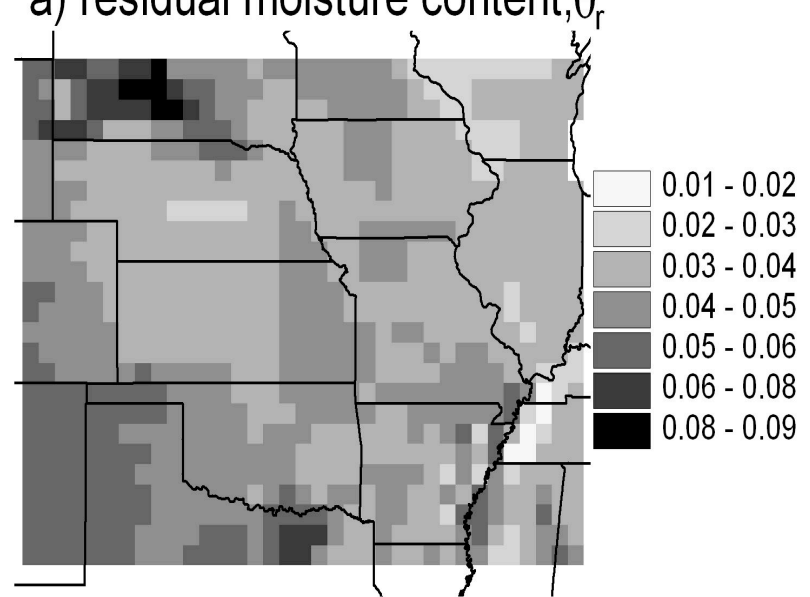

c) bubbling pressure, $\Psi_{\mathrm{s}}$

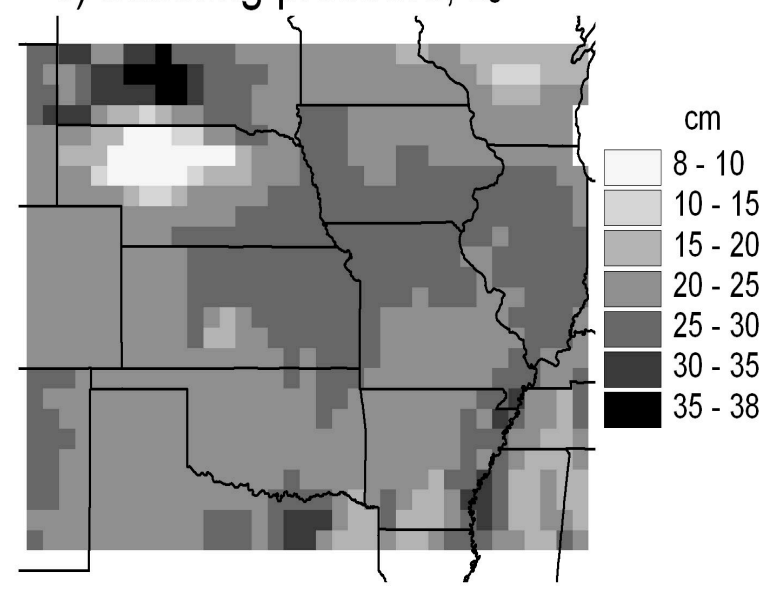

b) pore size distribution index, $\mathrm{m}$

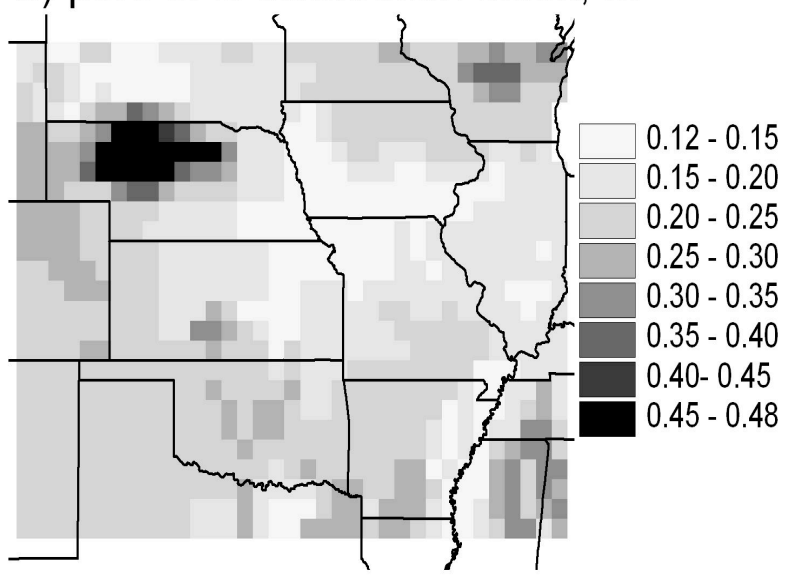

d) saturated hydraulic conductivity, $\mathrm{K}_{\mathrm{s}}$

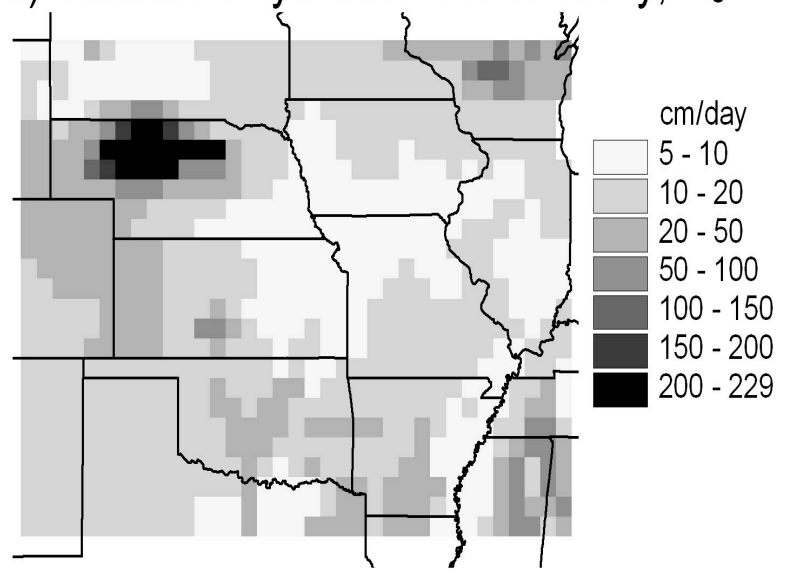

Fig. 13. Root-zone estimates of (a) residual moisture content, (b) pore size distribution index, (c) bubbling pressure, and (d) saturated hydraulic conductivity.

\section{Summary and conclusions}

The SDEM as coupled to the SW canopy model has been applied to the central United States over a half-degree grid using vegetation, soil and climate data from the Vegetation/Ecosystem Modeling and Analysis Project (VEMAP), among other sources. A very good match of modeled mean annual runoff to contours of streamflow was achieved with only minimal calibration of two evapotranspiration parameters, indicating that mean annual evapotranspiration is approximated well by the coupled models.

The interannual variation in peak green LAI is modeled through application of the hypothesis that, in any year in which water is significantly limiting, vegetation will draw soil moisture down in the latter half of the growing season approximately to the point at which the vegetation just begins to experience water stress. The hypothesis is applied to maximize the annual peak in green LAI, within upper and lower bounds, by scaling the seasonal LAI curve by a single fac- tor. Grid-cell specific curves were determined from NDVIbased estimates of green LAI. For the water-limited grassland region, comparison of the means of model-determined peak green LAI and those of the unaltered NDVI-based observations with ground-based observations of LAI and with a gridded datasets of above-ground net primary production indicated that the model-determined values are at least as accurate as the unaltered observations. The lack of positive correlation between accumulated precipitation and the peak in observed green LAI for vegetation in the humid half of the study region suggest that the optimization hypothesis is of limited use in this region. However, the somewhat arbitrary upper bound of six in both observed and modeled green LAI may be masking greater spatial and interannual variability and, consequently, the role of water in determining the long-term mean peak, particularly in the forested areas.

The partitioning of evapotranspiration in model results showed little dependence on climate and vegetation type, with most of the variation across the study region attributable 


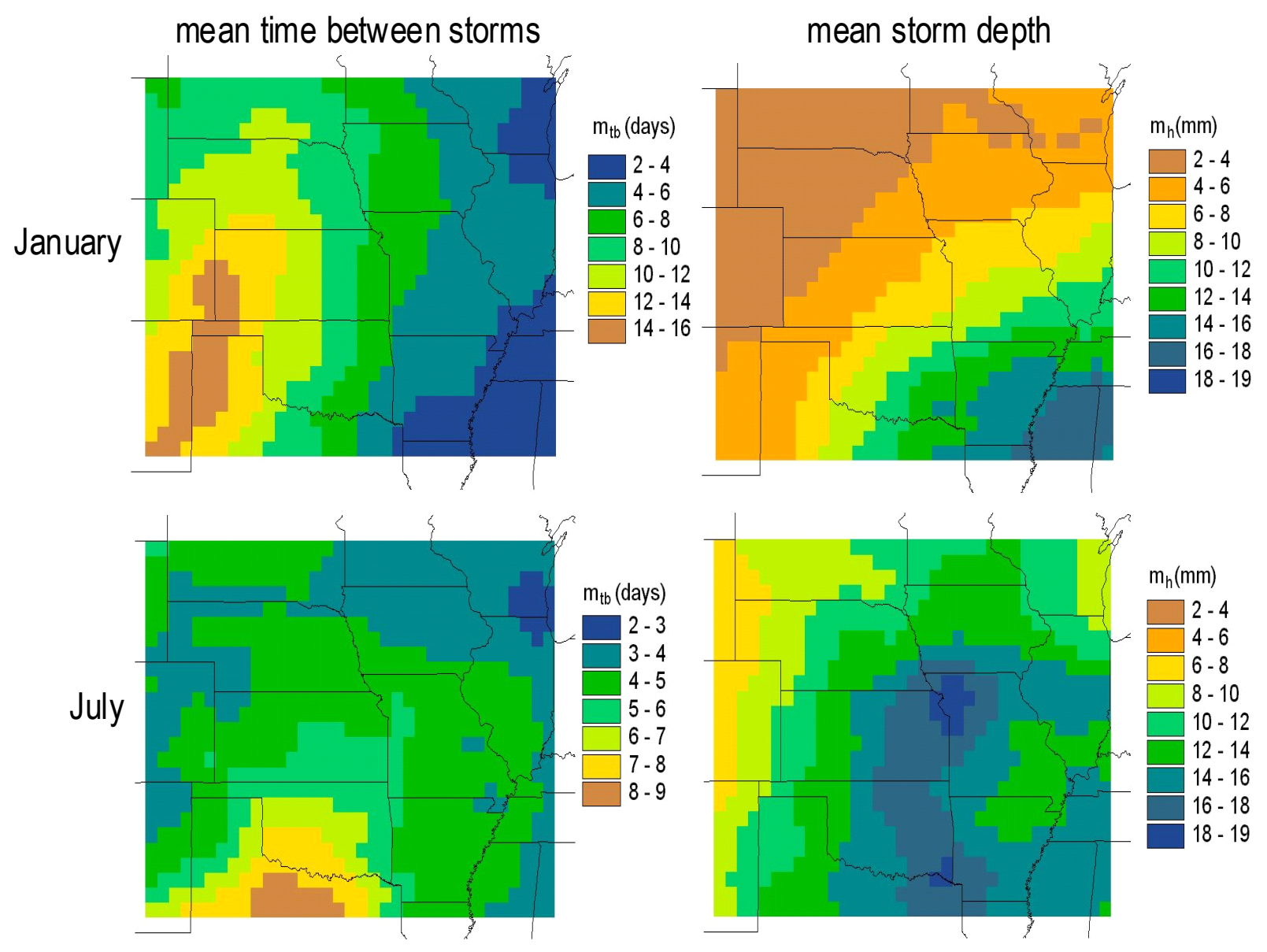

Fig. 14. Estimates of two of the statistics of the Poisson rectangular-pulse stochastic precipitation model for January and July.

to soil texture and the resultant differences in vegetation density. The implication is that the higher (lower) soil moisture content in wetter (drier) climates is more-or-less offset by the greater (lesser) amount of energy available at the soil surface. At the low end, with approximately $25-35 \%$ of annual average evapotranspiration being soil evaporation, are mostly soils with high sand content. At the high end, with $60-70 \%$ as soil evaporation, are soils with high clay content. The results for grasslands and crops are well supported by empirical observations in the literature. However, eddycovariance studies from two deciduous forests near the study region suggest that the model overestimates soil evaporation in humid forests by a factor of as much as two. This calls into question both the upper bound of six for the LAI and the accuracy of the Shuttleworth-Wallace model (as coupled to the SDEM) for the heterogeneous, multi-level canopies of forests, woodlands and savannas. In general, our results and their validation help to clarify the wide-ranging results in the partitioning of evapotranspiration that have been produced by other SVATS.

\section{Appendix A}

\section{Parameter estimation}

\section{A1 Soil hydraulic parameters}

The soil hydraulic parameters in the SDEM are those of Brooks and Corey (1966), who formulate the dependency of the soil matric potential on soil moisture content as

$\Psi(s)=\Psi_{\mathrm{S}} s^{-1 / m}$

where $\Psi(s)$ is the soil matric potential at a relative soil saturation of $s, \Psi_{\mathrm{s}}$ is the bubbling matric potential (i.e., the value at which air entry begins), and $m$ is the pore size distribution index. $s$ is defined by

$s=\frac{\theta_{t}-\theta_{\mathrm{r}}}{n_{\mathrm{t}}-\theta_{\mathrm{r}}}$

where $\theta_{\mathrm{t}}$ is the total volumetric soil water content, $\theta_{\mathbf{r}}$ is the residual volumetric soil water content, and $n_{\mathrm{t}}$ total porosity. Brooks and Corey formulate the dependency of the unsaturated hydraulic conductivity on $s$ as

$K(s)=K_{\mathrm{s}} s^{\mathrm{c}}$ 
where $c$ is the pore disconnectedness index, which the authors show to be related to the pore size distribution index by

$c=\frac{2+3 m}{m}$

Grid-cell mean bulk density and percentages of sand, silt and clay from the VEMAP database were used to estimate values of the Brooks-Corey soil hydraulic parameters. Those data are given for two soil layers: $0-50 \mathrm{~cm}$ and $50-150 \mathrm{~cm}$, where the data for the former are used for root zone and the data for the latter are used for the recharge zone, regardless of the actual values used for the depth of the soil layers. Bulk density was converted to total porosity with the standard assumption of a mineral density of $2.65 \mathrm{~g} / \mathrm{cm}^{3}$. In order to capture the signigicant variability of hydraulic properties within textural classes due differences in grain-size distribution, Kochendorfer (2005) modeled the dependence of $\theta_{\mathrm{r}}, \Psi_{\mathrm{s}}$ and $m$ on sand and clay percentages by multivariate linear regression. The values of texture-specific hydraulic parameters reported by Rawls et al. (1982) were assigned to the midpoint values of sand and clay percentages for the corresponding texture class on the USDA triangle. The results of application of the regression equations to the VEMAP sand and clay percentages for the $0-50 \mathrm{~cm}$ layer are presented in Fig. 13a-c. Following Rawls et al. (1982), Kochendorfer (2005) related the BrooksCorey parameters to $K_{\mathrm{S}}$ using an equation derived by Brutsaert (1967) based on a permeability model developed by Childs and Collis-George (1950). The equation was scaled to fit the textural-class geometric means reported by Cosby et al. (1984) and Rawls et al. (1982). Shown in Fig. 13d are the results for the root zone after a lower limit of $5.0 \mathrm{~cm} / \mathrm{d}$ was placed on $K_{\mathrm{s}}$.

\section{A2 Storm statistics}

Kochendorfer (2005) derived monthly values for the statistics of the PRP precipitation model from hourly observations of precipitation as compiled by the National Climatic Data Center (NCDC) and made available on CD-ROM by EarthInfo, Inc. (EarthInfo, 1999). Those observations were taken by recording rain gauges located at National Weather Service, Federal Aviation Administration, and Cooperative Observer stations. Thousands of these stations began making observations in and soon after 1948 and continue through the present. The 50-year period from 1949 to 1998 was selected for estimation of the parameter values of the precipitation model. Stations in the NCDC database were included in the analysis if they have records for at least 40 of the 50 years and have no more than $20 \%$ missing data for the available years. Within an area extending $2.5^{\circ}$ latitude and longitude beyond the boundaries of the study region, 706 stations met those criteria. Ordinary kriging (detailed descriptions of which can be found elsewhere; e.g., Kitanidis, 1993) was selected a priori as the preferred method for interpolating the station statistics to the half-degree grid of the study region. The results for
January and July are presented in Fig. 14 for two of the more important statistics: $m_{\mathrm{tb}}$, the mean time between storms, and $m_{\mathrm{h}}$, the mean depth of storms. The former primarily controls the frequency with which stage-two soil evaporation is reached, while the latter primarily controls the partitioning between infiltration and surface runoff.

In an equilibrium calculation of the monthly water balance, the PRP statistics are all that are needed (see Kochendorfer and Ramirez, 2010). In Eagleson's application of his original model to estimating the interannual variability of runoff, he perturbs the model with variations in annual precipitation as sampled from its PDF (as predicted by the PRP model), while leaving the values of the PRP statistics alone (Eagleson, 1978g). However, a given value of precipitation over some period that is larger (smaller) than long-term mean increases the likelihood of greater (fewer) number of storms for that time period, as well the likelihood for deeper (shallower) storms than the mean depth. By applying Bayes' Theorem to the PRP model, Salvucci and Song (2000) derive probability distributions for the number of storms and the mean storm depth over a given period conditioned on the actual precipitation for that period. We use their methodology to condition the monthly mean values of the PRP statistics in each month on the observed VEMAP/PRISM total for the given month and grid cell. Details can be found in Kochendorfer (2005).

\section{A3 Monthly climate variables}

In addition to being the source of monthly precipitation, the VEMAP database provided monthly mean temperatures, as well as two other variables necessary for implementation of the SW model: incoming solar radiation and water vapor pressure. Four variables necessary for implementation of the SW model not included in the VEMAP database are net longwave radiation, surface albedo, air pressure and monthly windspeed (the last being provided only as a seasonal climatology). Net long-wave radiation was estimated from cloudiness, surface temperature and humidity using a methodology outlined by Sellers (1965). Cloudiness was estimated as a linear function of the ratio of solar radiation incident at the surface to that incident at the top of the atmosphere, with the slope and intercept visually calibrated to maps of a climatology of observed percent sunshine (Baldwin, 1973). Due to a lack of remotely sensed surface albedo over the entire modeling period, a gridded, monthly climatology created by Hobbins et al. (2001) based on Gutman (1988) was used. Surface air pressure and surface windspeed were interpolated from monthly values produced by the NOAA-CIRES Center for the Diagnosis of Climate (http://www.cdc.noaa.gov/ cdc/reanalysis/) from results of the NCEP/NCAR reanalysis project (Kalnay et al., 1996). The remaining, water-vaporrelated variables were calculated from vapor pressure, air temperature and air pressure using standard formulas presented by Shuttleworth (1993). 
Acknowledgements. This work was partially supported by the National Institute for Global Environmental Change through the US Department of Energy (Cooperative Agreement DE-FC0390ER61010). Some of this work was performed while the second author was on sabbatical leave at the Swiss Federal Institute of Technology (ETH-Z) whose support is gratefully acknowledged. We sincerely acknowledge the review comments of the editor and two anonymous reviewers.

Edited by: S. Manfreda

\section{References}

Ashktorab, H., Pruitt, W. O., and Paw, K. T.: Partitioning of evapotranspiration using lysimeter and micro-Bowen-ratio system, J. Irrig. Drai. E.-ASCE, 120(2), 450-464, 1994.

Baldwin, J. L.: Climates of the United States, US Department of Commerce, National Oceanic and Atmospheric Administration, Washington, DC, 113 pp., 1973.

Bond, J. J. and Willis, W. O.: Soil water evaporation: surface residue rate and placement effects, Soil Sci. Soc. Am. Pro., 33, 445-448, 1969.

Boyer, J. S.: Resistances to water transport in soybean, bean, and sunflower, Crop Sciences, 11, 403-407, 1971.

Brooks, R. H. and Corey, A. T.: Properties of porous media affecting fluid flow, J. Irrigation Drainage Division of American Society of Civil Engineers, IR2, 61-88, 1966.

Brutsaert, W.: Some methods of calculating unsaturated permeability, T. ASAE, 400-404, 1967.

Buermann, W., Wang, Y., Dong, J., Zhou, L., Zeng, X., Dickinson, R. E., Potter, C. S., and Myneni, R. B.: Analysis of a multiyear global vegetation leaf area index data set, J. Geophys. Res., 107(D22), 4646-4664, 2002.

Burt, C. M., Mutziger, A. J., Allen, R. G., and Howell, T. A.: Evaporation research: Review and interpretation, J. Irrig. Drain. E.ASCE, 131(1), 37-58, 2005.

Camillo, P. J. and Gurney, R. J.: A resistance parameter for bare-soil evaporation models, Soil Sci., 141(2), 95-105, 1986.

Childs, E. C. and Collis-George, N.: The permeability of porous materials, Proc. Roy. Soc. A, A201, 392-405, 1950.

Choudhury, B. J., DiGirolamo, N. E., Susskind, J., Darnell, W. L., Gupta, S. K., and Asrar, G.: A biophysical process-based estimate of global land surface evaporation using satellite and ancillary data - II. Regional and global patterns of seasonal and annual variations, J. Hydrol., 205(3-4), 186-204, 1998.

Choudhury, B. J. and Monteith, J. L.: A four-layer model for the heat budget of homogeneous land surfaces, Q. J. Roy. Meteor. Soc., 114, 373-398, 1988.

Cosby, B. J., Hornberger, G. M., Clapp, R. B., and Ginn, T. R.: A statistical exploration of the relationships of soil moisture characteristics to the physical properties of soils, Water Resour. Res., 20(6), 682-690, 1984.

Cowan, I. R.: Transport of water in the soil-plant-atmosphere system, J. Appl. Ecol., 2, 221-239, 1965.

Cowan, I. R. and Milthorpe, F. L.: Plant factors influencing the water status of plant tissues, in: Water Deficits and Plant Growth, Vol. 1: Development, Growth and Measurement, edited by: Kozlowski, T. T., Academic Press, New York, 137-193, 1968.
Daly, C., Neilson, R. P., and Phillips, D. L.: A statisticaltopographic model for mapping climatological precipitation, J. Appl. Meteorol., 33, 140-158, 1994.

Denmead, O. T.: Temperate cereals, in: Vegetation and the Atmosphere, edited by: Monteith, J. L., Academic Press, New York, 1-31, 1976.

Denmead, O. T. and Shaw, R. H.: Availability of soil water to plants as affected by soil moisture content and meteorological conditions, Agron. J., 54, 385-390, 1962.

Dickinson, R. E., Henderson-Sellers, A., and Kennedy, P. J. Biosphere-Atmosphere Transfer Scheme (BATS) Version 1e as Coupled to the NCAR Community Climate Model, NCAR Technical Note, National Center for Atmospheric Research, Boulder, CO, 1993.

Dugas, W. A., Hicks, R. A., and Gibbens, R. P.: Structure and function of C-3 and C-4 Chihuahuan Desert plant communities, Energy balance components, J. Arid Environ., 34(1), 63-79, 1996.

Eagleson, P. S.: Climate, soil, and vegetation: 1. Introduction to water balance dynamics, Water Resour. Res., 14(5), 705-712, 1978a.

Eagleson, P. S.: Climate, soil, and vegetation: 2. The distribution of annual precipitation derived from observed sequences, Water Resour. Res., 14(5), 713-721, 1978b.

Eagleson, P. S.: Climate, soil, and vegetation: 3. A simplified model of soil moisture movement in the liquid phase, Water Resour. Res., 14(5), 722-730, 1978c.

Eagleson, P. S.: Climate, soil, and vegetation: 4. The expected value of annual evapotranspiration, Water Resour. Res., 14(5), 731739, 1978d.

Eagleson, P. S.: Climate, soil, and vegetation: 5. A derived distribution of storm surface runoff, Water Resour. Res., 14(5), 740-748, 1978e.

Eagleson, P. S.: Climate, soil, and vegetation: 6. Dynamics of the annual water balance, Water Resour. Res., 14(5), 749-764, $1978 f$.

Eagleson, P. S.: Climate, soil, and vegetation: 7. A derived distribution of annual water yield, Water Resour. Res., 14(5), 765-776, 1978g.

EarthInfo: CDROM of National Climate Data Center Hourly Precipitation Records, EarthInfo, Boulder, CO, 1999.

Epstein, H. E., Lauenroth, W. K., Burke, I. C., and Coffin, D. P.: Productivity patterns of $\mathrm{C}_{3}$ and $\mathrm{C}_{4}$ functional types in the US great plains, Ecology, 78(2), 722-731, 1997a.

Federer, C. A.: A soil-plant-atmosphere model for transpiration and availability of soil water, Water Resour. Res., 15(2), 555-562, 1979.

Ferretti, D. F., Pendall, E., Morgan, J. A., Nelson, J. A., LeCain, D., and Mosier, A. R.: Partitioning evapotranspiration fluxes from a Colorado grassland using stable isotopes: Seasonal variations and ecosystem implications of elevated atmospheric $\mathrm{CO}_{2}$, Plant Soil, 254(2), 291-303, 2003.

Gardner, W. R.: Dynamic aspects of water availability to plants, Soil Sci., 89(2), 63-73, 1960.

Gardner, W. R. and Ehlig, C. F.: The influence of soil water on transpiration by plants, J. Geophys. Res., 68(20), 5719-5725, 1963.

Gebert, W. A., Graczyk, D. J., and Krug, W. R.: Average annual runoff in the United States, 1951-80, Online available at: http: //water.usgs.gov/pubs/. US Geological Survey, 1987.

Geraghty, J. J. and Miller, D. W.: Water Atlas of the United States, 
Water Information Center, Port Washington, 122 pp., 1973.

Gollan, T., Passioura, J. B., and Munnus, R.: Soil water status affects the stomatal conductance of fully turgid wheat and sunflower leaves, Aust. J. Plant Physiol., 13, 459-464, 1986.

Grimmond, C. S. B., Hanson, P. J., Cropley, F., Schmid, H. P., and Wullschleger, S.: Evapotranspiration rates at the Morgan Monroe State Forest Ameriflux site: a comparison of results from eddy covariance turbulent flux measurements and sap flow techniques, Proceedings of 15th AMS Symposium on Hydrology, American Meteorological Society, Long Beach, CA, 158-161, 2000.

Guswa, A. J., Celia, M. A., and Rodriguez-Iturbe, I.: Models of soil moisture dynamics in ecohydrology: a comparative study, Water Resour. Res., 38(9), 1166-1181, 2002.

Gutman, G.: A simple method for estimating monthly mean albedo from AVHRR data, J. Appl. Meteorol., 27, 973-988, 1988.

Havranek, W. M. and Benecke, U.: Influence of soil moisture on water potential, transpiration and photosynthesis of conifer seedlings, Plant. Soil., 49, 91-103, 1978.

Hazlett, D.: Leaf area development of four plant communities in the Colorado steppe, Am. Midl. Nat., 127, 276-289, 1992.

Hellkvist, J., Richards, G. P., and Jarvis, P. G.: Vertical gradients of water potential and tissue water relations in sitka spruce trees measured with the pressure chamber, J. Appl. Ecol., 11, 637667, 1973.

Hobbins, M. T., Ramírez, J. A., Brown, T. C., and Claessens, L. H. J. M.: The complementary relationship in estimation of regional evapotranspiration: The complementary relationship areal evapotranspiration and advection-aridity models, Water Resour. Res., 37(5), 1367-1387, 2001.

Hollinger, S. E. and Isard, S. A.: A soil moisture climatology of Illinois, J. Climate, 7, 822-833, 1994.

Jackson, R. B., Canadell, J., Ehleringer, J. R., Mooney, H. A., Sala, O. E., and Schulze, E. D: A global analysis of root distributions for terrestrial biomes, Oecologia, 108, 389-411, 1996.

Jackson, R. B., Schenk, H. J., Jobbagy, E. G., Canadell, J., Colello, R. E., Dickinson, R. E., Field, C. B., Friedlingstein, P., Heimann, M., Hibbard, K., Kicklighter, D. W., Kleidon, A., Neilson, R. P., Parton, W. J., Sala, O. E., and Sykes, M. T.: Belowground consequences of vegetation change and their treatment in models, Ecol. Appl., 10(2), 470-483, 2000.

Jarvis, P. G., James, G. B., and Landsberg, J. J.: Conifer forest, in: Vegetation and the Atmosphere, edited by: Monteith, J. L., Academic Press, New York, 171-236, 1976.

Kalnay, E., Kanamitsu, M., Kistler, R., Collins, W., Deaven, D., Gandin, L., Iredell, M., Saha, S., White, G., Woollen, J., Zhu, Y., Chelliah, M., Ebisuzaki, W., Higgins, W., Janowiak, J., Mom K. C., Ropelewski, C., Wang, J., Leetmaa, A., Reynolds, R., Jenne, R., and Joseph, D.: The NCEP/NCAR 40-year reanalysis project, B. Am. Meteorol. Soc., 77(2), 437-471, 1996.

Kitanidis, P. K.: Geostatistics, in: Handbook of Hydrology, edited by: Maidment, D. R., McGraw-Hill, New York, 20.1-20.39, 1993.

Kittel, T. G. F., Rosenbloom, N. A., Painter, T. H., Schimel, D. S., and Participants, V. M.: The VEMAP integrated database for modeling United States ecosystem/vegetation sensitivity to climate change, J. Biogeogr., 22(4-5), 857-862, 1995.

Klocke, N. L.: Water savings from crop residue in irrigated corn, Central Plains Irrigation Conference Proceedings, Colby, KS, 134-142, 2003.
Knight, D.: Leaf area dynamics of a shortgrass prairie in Colorado, Ecology, 54(3), 891-896, 1973.

Kochendorfer, J. P.: A monthly, two-soil-layer statitisticaldynamical water balance model for ecohydrologically focused climate impact assessment, Ph.D. dissertation, Department of Civil Engineering, Colorado State University, Fort Collins, CO, 211 pp., 2005.

Kochendorfer, J. P. and Ramírez, J. A.: Modeling the monthly mean soil-water balance with a statistical-dynamical ecohydrology model as coupled to a two-component canopy model, Hydrol. Earth Syst. Sci., 14, 2099-2120, doi:10.5194/hess-14-20992010, 2010.

Körner, C., Scheel, J. A., and Bauer, H.: Maximum leaf diffusive conductance in vascular plants, Photosynthetica, 13(1), 45-82, 1979.

Kramer, P. J.: Water Relations of Plants. Academic Press, New York, 489 pp., 1983.

Lafleur, P. M. and Rouse, W. R.: Application of an energy combination model for evaporation from sparse canopies, Agr. Forest Meteorol., 49, 135-153, 1990.

Larcher, W.: Physiological Plant Ecology, Springer-Verlag, New York, 297 pp., 1980.

Lawrence, D. M., Thornton, P. E., Oleson, K. W., and Bonan, G. B.: The Partitioning of Evapotranspiration into Transpiration, Soil Evaporation, and Canopy Evaporation in a GCM: impacts on Land - Atmosphere Interaction, J. Hydrometeorol., 8(3), 862880, 2007.

Leuning, R., Condon, A. G., Dunin, F. X., Zegelin, S., and Denmead, O. T.: Rainfall Interception and Evaporation from Soil Below a Wheat Canopy, Agr. Forest Meteorol., 67(3-4), 221238, 1994.

Los, S. O., Collatz, G. J., Sellers, P. J., Malstrom, C. M., Pollack, N. H., DeFries, R. S., Bounoua, L., Parris, M. T., Tucker, C. J., and Dazlich, D. A.: A global 9-yr biophysical land surface dataset from NOAA AVHRR data, J. Hydrometeorol., 1, 183-199, 2000.

Luxmoore, R. J. and Sharma, M. L.: Runoff responses to soil heterogeneity: Experimental and simulation comparisons for two contrasting watersheds, Water Resour. Res., 16(3), 675-684, 1980.

Mahfouf, J.-F., Ciret, C., Ducharne, A., Irannejad, P., Noilhan, J., Shao, Y., Thornton, P., Xue, Y., and Yang, Z.-L.: Analysis of transpiration results from the RICE and PILPS workshop, Global Planet. Change, 13, 73-88, 1996.

Massman, W. J.: A Surface-Energy Balance Method for Partitioning Evapotranspiration Data into Plant and Soil Components for a Surface with Partial Canopy Cover, Water Resour. Res., 28(6), 1723-1732, 1992.

Massman, W. J. and Ham, J. M.: An Evaluation of a SurfaceEnergy Balance Method for Partitioning Et Data into Plant and Soil Components for a Surface with Partial Canopy Cover, Agr. Forest Meteorol., 67(3-4), 253-267, 1994.

Monteith, J. L.: Evaporation and the environment, Symposia of the Society for Experimental Biology, 19, 205-234, 1965.

Neilson, R. P.: A model for predicting continental-scale vegetation distribution and water balance, Ecol. Appl., 5(2), 362-385, 1995.

Nemani, R. R. and Running, S. W.: Satellite monitoring of global land cover changes and their impact on climate, Climatic Change, 31(2), 395-413, 1995.

Newman, B. D., Wilcox, B. P., Archer, S. R., Breshears, D. D., 
Dahm, C. N., Duffy, C. J., McDowell, N. G., Phillips, F. M., Scanlon, B. R., and Vivoni, E. R.: Ecohydrology of waterlimited environments: a scientific vision, Water Resour. Res., 42, W06302, doi:10.1029/2005WR004141, 2006.

Newman, E. I.: Resistance to water flow in soil and plant: I. Soil resistance in relation to amounts of root: theoretical estimates, J. Appl. Ecol., 6, 1-112, 1969.

Noy-Meir, I.: Desert ecosystems: Environment and producers, Annual Review of Ecological Systems, 4, 25-51, 1973.

Penman, H. L.: Natural Evaporation from open water, bare soil and grass, P. Roy. Soc. A., A193, 120-145, 1948.

Peters, D. B. and Russell, M. B.: Relative water losses by evaporation and transpiration in field corn, Soil Sci. Soc. Am. Pro., 23(2), 170-173, 1959.

Phillip, J. R.: Theory of infiltration. Advances in Hydroscience, 5, 215-296, 1969.

Prince, S., Haskett, J., Steininger, M., Strand, H., and Wright, R.: Net primary production of US midwest croplands from agricultural harvest yield data, Ecol. Appl., 11(3), 1194-1205, 2001.

Rauner, J. L.: Deciduous Forest, in: Vegetation and the Atmosphere, edited by: Monteith, J. L., Academic Press, New York, 241-262, 1976

Rawls, W. J., Brakensiek, D. L., and Saxton, K. E.: Estimation of Soil Water Properties, T. ASAE, 1316-1320, 1982.

Richter, H.: The water status in the plant; experimental evidence, in: Water and Plant Life, edited by: Lange, O. L., Kappe, L., and Schulze, E. D., Problems and Modern Approaches, SpringerVerlag, New York, 42-58, 1976.

Ripley, E. A. and Redmann, R. E.: Grassland, in: Vegetation and the Atmosphere, Monteith, J. L., Academic Press, New York, 351-396, 1976.

Ritchie, J. T., Rhoades, E. D., and Richardson, C.,W.: Calculating evaporation from native grassland watersheds, T. ASAE, 19(6), 1098-1103, 1976.

Robock, A., Vinnikov, K. Y., Srinivasan, G., Entin, J. K., Hollinger, S. E., Speranskaya, N. A., Liu, S., and Namkhai, A.: The global soil moisture data bank, B. Am. Meteorol. Soc., 81, 1281-1299, 2000.

Rodriguez-Iturbe, I.: Ecohydrology: A hydrologic perspective of climate-soil-vegetation dynamics, Water Resour. Res., 36(1), 3$10,2000$.

Ross, J.: Radiative transfer in plant communities, in: Vegetation and the Atmosphere, edited by: Monteith, J. L., Vol. 1: Principles, Academic Press, 13-55, 1975.

Running, S. W. and Hunt, E. R.: Generalization of a forest ecosystem process model for other biomes, BIOME-BGC, and an application for global-scale models, Scaling Physiological Processes: Leaf to Globe, Academic Press, Inc, 141-158, 1993.

Rutter, A. J.: The hydrological cycle in vegetation, in: Vegetation and the Atmosphere, edited by: Monteith, J. L., Vol. 1: Principles, Academic Press, 111-154, 1975.

Sala, O. E., Lauenroth, W. K., Parton, W. J., and Trlica, M. J.: Water status of soil and vegetation in a shortgrass steppe, Oecologia, 48, 327-331, 1981.

Sala, O. E., Parton, W. J., Joyce, L. A., and Lauenroth, W. K.: Primary production of the central grassland region of the United States, Ecology, 69(1), 40-45, 1988.

Salvucci, G. D. and Song, C.: Derived distributions of storm depth and frequency conditioned on monthly total precipita- tion: Adding value to historical and satellite-derived estimates of monthly precipitation, J. Hydrometeorol., 1, 113-120, 2000.

Schenk, H. J. and Jackson, R. B.: The global biogeography of roots, Ecol. Monogr., 72(2), 311-3228, 2002.

Schulze, E. D., Kelliher, F. M., Korner, C., Lloyd, J., and Leuning, R.: Relationships among maximum stomatal conductance, ecosystem surface conductance, carbon assimilation rate, and plant nitrogen nutrition: a global ecology scaling exercise, Annu. Rev. Ecol. Syst., 25, 629-660, 1994.

Scurlock, J. M. O., Asner, G. P., and Gower, S. T.: Global leaf area index data from field measurements, Oak Ridge National Laboratory Distributed Active Archive Center, 1938-2000, 2001.

Sellers, P. J., Heiser, M. D., and Hall, F. G.: Relation between surface conductance and spectral vegetation indices at intermediate $\left(100 \mathrm{~m}^{2}\right.$ to $15 \mathrm{~km}^{2}$ ) length scales, J. Geophys. Res., 97(D17), 19033-19059, 1992.

Sellers, P. J., Randall, G. J., Collatz, G. J., Berry, J. A., Field, C. B., Dazlich, D. A., Zhang, C., Collelo, G. D., and Bounoua, L.: A revised land surface parameterization $(\mathrm{SiB} 2)$ for atmospheric GCMs, Part I: Model formulation, J. Climate, 9, 676-705, 1996.

Sellers, W. D.: Physical Climatology, The University of Chicago Press, Chicago, 272 pp., 1965.

Shuttleworth, W. J.: Evaporation, in: Handbook of Hydrology, edited by: Maidment, D. R., McGraw-Hill, New York, 4.1-4.53, 1993.

Shuttleworth, W. J. and Wallace, J. S.: Evaporation from sparse crops: an energy combination theory, Q. J. Roy. Meteor. Soc., 111, 839-855, 1985.

Smith, D. M. and Allen, S. J.: Measurement of sap flow in plant stems, J. Exp. Bot., 47, 1833-1844, 1996.

Stannard, D. I. and Weltz, M. A.: Partitioning evapotranspiration in sparsely vegetated rangeland using a portable chamber, Water Resour. Res., 42(2), W02413, doi:10.1029/2005WR004251, 2006.

Thornthwaite, C. W.: An approach toward a rational classification of climate, Geogr. Rev., 38, 55-94, 1948.

Tieszen, L. L., Reed, B. C., Bliss, N. B., Wylie, B. K., and DeJong, D. D.: NDVI, $\mathrm{C}_{3}$ and $\mathrm{C}_{4}$ production, and distributions in great plains grassland land cover classes, Ecol. Appl., 7(1), 5978, 1997.

USGS: Map of Seasonal Land Cover Regions, US Geological Survey, US Department of Interior, Washington DC, 1993.

van den Honert, T. H.: Water transport in plants as a catenary process, Discuss. Faraday Soc., 3, 146-153, 1948.

Villabalobos, F. J. and Fereres, E.: Evaporation measurements beneath corn, cotton, and sunflower canopies, Agron. J., 82, 1153 1159, 1990.

Wilson, K. B., Hanson, P. J., Mulholland, P. J., Baldocchi, D. D., and Wullschleger, S. D.: A comparison of methods for determining forest evapotranspiration and its components: sap-flow, soil water budget, eddy covariance and catchment water balance, Agr. Forest Meteorol., 106(2), 153-168, 2001.

Woodward, F. I.: Climate and Plant Distribution, Cambridge University Press, Cambridge, 174 pp., 1987.

Zheng, D., Prince, S., and Wright, R.: Terrestrial net primary production estimates for $0.5^{\circ}$ grid cells from field observations: a contribution to global biogeochemical modeling, Global Change Biol., 9, 46-64, 2003. 